NBER WORKING PAPER SERIES

\title{
IMMIGRANT EMPLOYMENT AND EARNINGS GROWTH IN CANADA AND THE U.S.: EVIDENCE FROM LONGITUDINAL DATA
}

\author{
Neeraj Kaushal \\ Yao $\mathrm{Lu}$ \\ Nicole Denier \\ Julia Shu-Huah Wang \\ Stephen J. Trejo \\ Working Paper 21591 \\ http://www.nber.org/papers/w21591 \\ NATIONAL BUREAU OF ECONOMIC RESEARCH \\ 1050 Massachusetts Avenue \\ Cambridge, MA 02138 \\ September 2015
}

The authors are grateful for support by the National Science Foundation (SES 1226546), the Russell Sage Foundation, and the Columbia Population Research Center with funding from the Eunice Kennedy Shriver National Institute of Child Health and Human Development (R24 HD058486). Some of the analyses presented in this paper were conducted at the Quebec Interuniversity Centre for Social Statistics, which is part of the Canadian Research Data Centre Network (CRDCN). The services and activities provided by the QICSS are made possible by the financial or in-kind support of the SSHRC, the CIHR, the CFI, Statistics Canada, the FRQSC and the Quebec universities. The views expressed in this paper are those of the authors, and not necessarily those of the CRDCN, its partners, or the National Bureau of Economic Research.

NBER working papers are circulated for discussion and comment purposes. They have not been peerreviewed or been subject to the review by the NBER Board of Directors that accompanies official NBER publications.

(C) 2015 by Neeraj Kaushal, Yao Lu, Nicole Denier, Julia Shu-Huah Wang, and Stephen J. Trejo. All rights reserved. Short sections of text, not to exceed two paragraphs, may be quoted without explicit permission provided that full credit, including $(\mathcal{C}$ notice, is given to the source. 
Immigrant Employment and Earnings Growth in Canada and the U.S.: , Evidence from Longitudinal Data

Neeraj Kaushal, Yao Lu, Nicole Denier, Julia Shu-Huah Wang, and Stephen J. Trejo

NBER Working Paper No. 21591

September 2015

JEL No. J15,J18

\begin{abstract}
We study the short-term trajectories of employment, hours worked, and real wages of immigrants in Canada and the U.S. using nationally representative longitudinal datasets covering 1996-2008. Models with person fixed effects show that on average immigrant men in Canada do not experience any relative growth in these three outcomes compared to men born in Canada. Immigrant men in the U.S., on the other hand, experience positive annual growth in all three domains relative to U.S. born men. This difference is largely on account of low-educated immigrant men, who experience faster or longer periods lof relative growth in employment and wages in the U.S. than in Canada. We further compare longitudinal and cross-sectional trajectories and find that the latter over-estimate wage growth of earlier arrivals, presumably reflecting selective return migration.
\end{abstract}

Neeraj Kaushal

Columbia University

School of Social Work

1255 Amsterdam Avenue

New York, NY 10027

and NBER

nk464@columbia.edu

Yao Lu

Columbia University

606 West 122nd Street, 614 Knox,

New York, NY 10027

y12479@columbia.edu

Nicole Denier

McGill University

Leacock Building

855 Sherbrooke Street West

Montreal, Quebec H3A 2T7, Canada

nicole.denier@mail.mcgill.ca
Julia Shu-Huah Wang

Columbia University

1255 Amsterdam Avenue

New York, NY 10027

jw2674@columbia.edu

Stephen J. Trejo

Department of Economics

University of Texas at Austin

2225 Speedway Stop C3100

Austin, TX 78712

and NBER

trejo@austin.utexas.edu 
Over recent decades, Canada and the United States, two North American neighbors with contrasting immigration policies, have experienced extraordinary growth in their immigrant populations. Between 1990 and 2010, the U.S. foreign-born population more than doubled and Canada's increased by nearly 56 percent. ${ }^{1}$ Economic assimilation of immigrants has drawn considerable policy and academic interest in both countries. But, surprisingly, there is very little comparative research that investigates the relative labor market experiences of immigrants in the two countries, and none has captured the post-1990 experience (trajectories). The scant existing comparative research on immigrant economic assimilation is based on cross-sectional data, which is likely to yield biased trajectories of employment and earnings on account of selection in immigration as well as return migration (Antecol, Kuhn, and Trejo, 2006). These biases are likely to compound in comparative research if, as documented in recent studies, relative selection patterns differ across the two destinations (Bonikowska et al., 2011; Kaushal and Lu, 2014). Longitudinal data are also more suitable to study labor market trajectories, whereas crosssectional data essentially capture wage levels but not wage growth.

To bridge this knowledge gap, in this paper we study the employment and earnings trajectories of immigrants to the U.S. and Canada using longitudinal data covering the most recent period. These two major immigrant destinations are comparable on many cultural and institutional domains but also have several critical differences, described below, that may affect the economic assimilation of immigrants. Because many challenges relating to immigrant

\footnotetext{
${ }^{1}$ Figures are from: International Migration Statistics, Migration Policy Institute. http://www.migrationpolicy.org/programs/data-hub/international-migration-statistics In proportion to overall population, the foreign born constitute a larger share of the Canadian population (21\% as of 2011) compared to the US (13\% as of 2011) (Statistics Canada, 2011; US Census Bureau, 2015a).
} 
incorporation are similar, comparative research has considerable policy relevance for both countries. In general, cross-national research on immigration is important as it creates opportunities for nation-states to draw from the experience of others; it also opens domestic policy in receiving countries to international scrutiny that is often not bound by the nuances of domestic immigration policy debates.

The post-1990 immigration, the focus of our study, is important not just for its sheer size but also for the changing composition (characteristics) of new arrivals, which is at least partly driven by the divergent immigration policies of the two nations. Since the mid-1990s, Canada has modified its point system to place greater emphasis on the educational attainment and English/French language proficiency of immigrants, and less significance on occupational demand (Beach, Green, and Worswick, 2006). ${ }^{2}$ Further, the past policy of linking immigration levels to the economy's absorptive capacity over the business cycle has been relinquished in favor of higher immigration irrespective of prevailing economic conditions. In recent years, Canada has included preference to employer nomination via the Provincial Nominee program and the Canadian experience class (Pandey and Townsend, 2011; Baglay, 2012).

The U.S., on the other hand, while continuing with family preference as the primary mode of granting permanent residency, has made changes to allow an increased influx of immigrants and temporary workers to cater to the labor market needs of the economy. The Immigration Act of 1990 doubled the annual quota of employment based permanent immigration

\footnotetext{
${ }^{2}$ In 1992, the Canadian government allocated 12 points (out of 100) to high education and 15 to French or English proficiency. By 2006, prospective immigrants with a bachelor's degree received 20 points (out of 100), and those with a masters or Ph.D. received 25 points. The points allocated to language proficiency were raised to 24 . Despite the focus on the point system, in 2006 only around $20 \%$ of Canadian immigrants were adjudicated under the point system as principal applicants and another $25 \%$ as their family members (CIC, 2013). Research shows that family members' credentials in the skilled worker category are correlated with those of the principal applicant (Sweetman \& Warman, 2010).
} 
and created as well as expanded several categories of visas enabling short-term temporary migration for high-skilled workers or students pursuing higher education. In recent years, these inflows have exceeded new immigration via family unification. ${ }^{3}$ On the other end, since the mid1990s, an increasingly large number of undocumented immigrants, who are mostly low educated and disproportionately from Mexico, have also entered the U.S. (Passel and Cohn, 2012, Hoefer, Rytina, and Campbell, 2006). ${ }^{4}$

Partly on account of the changes in immigration and temporary migration policies, selection patterns of immigrants to Canada and the U.S. have changed significantly. Kaushal and $\mathrm{Lu}$ (2014) document a relatively positive selection of immigrants to Canada (compared to the U.S.) in terms of educational attainment and host country language proficiency, the two attributes that have gained significance in the Canadian points system. They also find that new immigrants to Canada have lower initial earnings compared to Canadian natives or recent immigrants in the U.S., which leads them to conclude that while the Canadian point system has resulted in positive selection on certain measurable attributes, it has not been successful in capturing unobserved skills of immigrants that cannot be measured at entry and remain outside the domain of the points system (i.e., motivations, skill transferability). Bonikowska et al. (2011) also demonstrate a growing wage disadvantage among university-educated recent immigrants compared to natives in Canada, but not in the U.S. ${ }^{5}$

\footnotetext{
${ }^{3}$ All temporary workers on non-immigrant visas can, and often do, subsequently adjust their status to permanent residents. A growing proportion of new permanent residents in the U.S. in recent years have been temporary migrants already residing in the country. In $1986,37 \%$ of the foreign-born receiving permanent residency were temporary residents; by 2009, the proportion had increased to $59 \%$ (USDHS, 2012).

${ }^{4}$ Net inflows of undocumented migrants have been negligible since 2007 (Passel and Cohn, 2012).

${ }^{5}$ Researchers attribute the decline in entry earnings of successive immigrant cohorts in Canada to compositional shifts in language ability and region of birth, deterioration in returns to foreign
} 
Given these differential selection patterns, an important issue with considerable policy implications is: How have immigrants to Canada and the U.S. performed over time? Do they exhibit different patterns of economic assimilation after adjusting for characteristics at arrival? Do these patterns differ by immigrants' region of origin? These questions have important implications for future immigration in both countries and can guide immigration policy in other immigrant receiving countries. To answer these questions, we study the short-term trajectories of employment, hours worked, and real wage of immigrants in Canada and the U.S., using longitudinal data and applying person fixed effects models to control for time-invariant individual characteristics (including unobserved attributes of immigrants that are constant throughout the panel survey). Further, we compare our results based on longitudinal data with those from cross-sectional data to investigate possible bias in the latter.

\section{Previous research}

Research on the labor market assimilation of immigrants has evolved from earlier studies based on single cross-sectional data to studies of repeated cross-sections of censuses, and in more recent years, to studies using longitudinal data. ${ }^{6}$ In both Canada and the U.S., these studies document that immigrants suffer from an initial earning disadvantage but tend to close this gap over time. Estimates of earnings growth, however, differ substantially between cross-sectional and longitudinal studies with the former generating substantially higher estimates than the latter

labor market experience, and non-random sorting of immigrants across establishments in Canada's major cities and geographic regions (Aydemir and Skuterud 2005, 2008; Green and Worswick, 2009).

${ }^{6}$ See Chiswick (1978) and Borjas $(1985,1994)$ for cross-sectional research on U.S. immigrants, and see Baker and Benjamin (1994), Bloom et al. (1995), Frenette and Morissette (2005), Warman (2007), Warman and Worswick (2004) for research on Canadian immigrants. For longitudinal studies of immigrant earnings assimilation, see Borjas (1989), Duleep and Dowhan (2002), Hall and Farkas (2008), Hu (2000), Lubotsky (2007), and Kaushal (2011) for the U.S. and Banerjee (2009), Beenstock (2006), Li (2003), Picot and Piraino (2013) for Canada. 
(Borjas, 1989; Duleep and Dowhan, 2002; Hu, 2000; Lubotsky, 2007; Kaushal, 2011; Kim, 2012, Picot and Piraino, 2013).

There is limited comparative research on the labor market assimilation of immigrants in Canada and the U.S. Aydemir and Sweetman (2008) study the educational attainment and labor market outcomes of immigrants in Canada and the U.S. across generations using U.S. March Current Population Surveys from 1998 and 2004 and the 2001 Canadian Census. They conclude that in both countries the second generation has better educational and labor market outcomes than the first generation and similar or better outcomes compared to the third generation.

Only one published paper to our knowledge has explicitly studied the relative labor market assimilation of immigrants in Canada and the U.S. Using census data, Antecol, Kuhn, and Trejo (2006) studied employment and earnings assimilation of immigrants in Australia, Canada and the U.S. during the 1980s. They find that earnings assimilation is higher in the U.S. than in Canada or Australia, and employment assimilation is highest in Australia, followed by the U.S., and then Canada. These findings hold in separate analysis for immigrants from Europe and Asia, thus ruling out the possibility that the U.S. results were driven by Latin American immigrants. From the assimilation patterns across these three major immigrant destinations, Antecol and colleagues conclude that host-country labor market institutions (such as higher unemployment insurance and unionization in Australia and Canada compared to the U.S.) affect immigrant assimilation.

Antecol et al. (2006) is based on cross-sectional data, and arguably, their findings could be affected by selective immigration and return migration. In a study of immigrant earnings growth in the U.S., Lubotsky (2007) compares cross-sectional and longitudinal trajectories of immigrants in the U.S., and finds that estimates of earnings assimilation from longitudinal data 
are about half as large as estimates from repeated cross-sectional data. Picot and Piraino (2013), on the other hand, show that the immigrant-native earnings gap closes at the same pace in longitudinal and cross-sectional data. The combined evidence from these studies suggests that selection in return migration may be different in Canada compared to the US. Comparative studies using cross-sectional data would yield biased results if the selection pattern in immigration (and in return migration) is different for immigrants across the two countries. A comparative study with longitudinal data can address some aspects of selective immigration by controlling for time-invariant factors such as immigrants' base year (or entry level) characteristics.

Estimates based on longitudinal data are certainly not exempt from possible bias due to return migration and sample attrition. However, unlike cross-sectional analyses, longitudinal studies provide unbiased estimates of earnings growth for the immigrant population that is observed throughout the period of study (i.e. in all waves of the longitudinal data). As a further step, sensitivity analysis can be conducted using longitudinal data to evaluate the impact of sample attrition and return migration on the estimates of employment and earnings growth.

\section{Factors Influencing Economic Assimilation}

Immigrant economic assimilation across nations may differ due to both differences in immigrant characteristics at arrival as well as contexts in receiving countries, particularly differences in labor market institutions. Characteristics at arrival (immigrant selection) are also influenced by both immigration policy and receiving country contexts. Previous research documents that compared to the U.S., new immigrants to Canada have been more positively selected in terms of human capital attributes, but negatively selected in certain unobserved 
attributes that may affect earnings at arrival (Bonikowska et al., 2011; Kaushal and Lu, 2014). ${ }^{7}$

On account of these unobserved attributes and conditional on observed human capital characteristics, it is likely that immigrant assimilation may be faster in the U.S. than Canada.

How will differences in immigration policy influence economic assimilation? The answer depends on how effectively the immigration policy of each country succeeds in "matching" the labor market needs of its economy. Since 1990, the U.S. has created a large number of nonimmigrant categories for temporary migration of skilled workers (e.g. H1B visa, L1-visa) and doubled the quota under employment preference category for permanent migration. ${ }^{8}$ In most cases, employers sponsor foreign workers for these visas, and their screening (or selection) is left to the employers. Thus, immigrants with work visas have jobs upon arrival. In Canada, the screening of new immigrants predominately comes under the Point system with a set of predetermined points for each attribute, often without pre-established employment links. The relative assimilation of professional immigrants who enter via the two systems is likely to provide some insight into how effectively these systems help in matching the economy's needs for high-skilled workers. ${ }^{9}$

In the post-1990 period, a large proportion of immigrants to the U.S. have been undocumented, and as a result have limited access to public services and almost no access to

\footnotetext{
${ }^{7}$ Observational studies in Canada indicate that immigrants face a considerable degree of occupational mismatch, implying presence of obstacles that may limit immigrants in achieving their full potential (Reitz, 2001).

${ }^{8}$ About $65 \%$ of permanent immigration to the U.S. and between $20-26 \%$ of the permanent migration to Canada was family migration during our study period 1996-2008 (Government of Canada, 2014; US Department of Homeland Security, 2014). However, in recent years, a large proportion of foreigners who acquire permanent residency in the U.S. via family unification enter the country on temporary visas - including many with employer-sponsored visas.

${ }^{9}$ Unfortunately, it is not possible to directly test this because our data do not include information on class of entry. However, fixed effects models do help account for differences in earnings across entry classes within a country.
} 
programs that ease integration (e.g., unemployment insurance). Given relatively fewer sources of support, the survival of the undocumented requires that their skills match the needs of the labor market and those not able to secure jobs are more likely to return to their countries of origin. Thus, the observed economic assimilation of the undocumented, who are predominantly loweducated and from Latin America, is likely to be high.

Labor market institutions in Canada and the U.S. differ in important ways. Canada has stronger labor unions, higher minimum wages, and more generous unemployment insurance and welfare systems (O'Connor et al., 1999). The minimum insurable employment effort necessary to seek unemployment benefits is 12 to 20 weeks in Canada and 1 year in the U.S. (Government of Canada, 2010; U.S. Department of Labor, 2013). The maximum period that an individual can receive unemployment benefits is 26 weeks in the U.S. and 36 to 45 weeks (for someone with 1 year of insurable employment) in Canada. ${ }^{10}$ Riddell and Kuhn (2007) find part-year employment in New Brunswick (Canada) to be double the rate of part-year employment in Maine (the U.S.) and attribute two-thirds of the difference to the more generous unemployment insurance system in Canada. In addition, the wage floor is higher in Canada than the U.S.: for instance, in 2000, the minimum wage was 43 percent of the average wage in Canada and 36 percent of the average wage in the U.S. (Neumark \& Wascher, 2014). Overall, differences in institutional environments in the two countries influence the labor force engagement and wage profiles of the native-born, and may, in a broadly similar way, impact immigrant economic integration. For instance, a compressed wage distribution may result in lower wage growth for immigrants in Canada (than in the U.S.), especially at the top or the lower end of the wage distribution, which in turn may

\footnotetext{
${ }^{10}$ Regional differences in unemployment insurance in Canada, however, may result in unemployment benefits that immigrants receive in major urban areas with low unemployment rates to be lower than the benefits that immigrants receive in major urban areas in the US.
} 
reduce incentives to invest in future labor market skills further limiting labor market assimilation (Antecol et al., 2006).

Immigrants often face delays or difficulty in obtaining work in the types of occupations for which they are trained, resulting in lower levels of employment or earnings at arrival than comparable natives. Extant research shows that immigrants in Canada are less likely than the native-born to work in occupations for which they have trained, especially in regulated occupations, like engineering and medicine (Boyd, 2013; Boyd \& Thomas, 2002; Boyd \& Schellenberg, 2007; Girard \& Smith, 2012; McDonald, Warman, \& Worswick, 2012; Wald \& Fang, 2008). In the U.S., research similarly shows that immigrants tend to be over-educated for the occupations in which they work (Beckhusen, Florax, Poot, \& Waldorf, 2013; Chiswick \& Miller, 2009; Mattoo, Neagu, \& Ozden, 2008). The issue is likely to be of greater relevance in Canada, though, as many immigrants are selected on the basis of points determined largely by human capital rather than employer sponsorship. ${ }^{11}$ We therefore expect that both levels of employment and wage growth will be higher in the U.S. than in Canada, as the employer nomination system facilitates more successful, although not perfect, occupational matching.

To sum up, differences in immigrant selection patterns, labor market institutions and immigration policies in the two countries suggest that immigrant economic assimilation is likely to be faster in the U.S. than in Canada. In the empirical analysis, we study three dimensions of economic assimilation - employment, hours worked and real wages. Our goal is to study how these forces jointly shape the labor market trajectories of immigrants in the two countries. The

\footnotetext{
${ }^{11}$ McDonald et al. (2012) find that foreign-trained doctors in Canada faced a lower probability of working as a physician than foreign-trained doctors in the U.S., which they attribute to differences in selection policies.
} 
focus is not on separating the respective role of these forces, which we are not able to do in a two-country comparison.

\section{Data and Measures}

We use the Canadian Survey of Labour and Income Dynamics (SLID) Panels 2-5 for 1996, 1999, 2002, and 2005, and the U.S. Survey of Income and Program Participation (SIPP) Panels in 1996, 2001 and 2004, covering roughly the same period (1996-2008). Both datasets are longitudinal. The baseline surveys of both SIPP and SLID are nationally representative (US Census Bureau, 2015; Statistics Canada, 2012). Their survey administration is somewhat different. Each SLID panel spans six years, with respondents completing annual interviews. A new panel is introduced every three years such that at any point in time SLID contains two panels. SIPP panels, on the other hand, last 3 to 4 years (36 to 48 months). ${ }^{12}$ Respondents are interviewed every four months about their employment and earnings in the previous four months. To improve comparability of these two datasets, we conduct analysis by restricting the Canadian samples to the first four years of each panel and all outcomes are measured annually. ${ }^{13}$ Further, all longitudinal analysis is restricted to samples with at least two observations on a given outcome.

The samples are restricted to individuals aged 25 to 59 years in the first observed year (base year) of the survey for each panel and who arrived in the host country after age 16. ${ }^{14}$

\footnotetext{
${ }^{12}$ The 1996 and 2004 Panels span 48 months and the 2001 is 36 months.

${ }^{13} \mathrm{We}$ also conducted analysis keeping all six years of data for SLID and the results were similar. ${ }^{14} \mathrm{We}$ restrict the sample to immigrants who entered host country after age 16 to ensure our results are not driven by differences in age at arrival. In the US sample, exclusion of persons who arrived at age 16 or before lowers the sample by $2.3 \%$, exclusion of students reduces the sample by $8.1 \%$, exclusion of immigrants from Canada lowers the sample by $0.2 \%$. In the Canadian sample, overall around $10 \%$ of the sample is excluded, with the vast majority of those excluded being students. For Canada, we could not release excluded numbers for each category separately
} 
Individuals enrolled in school in the reference year are excluded from the analysis as are individuals who are institutionalized or living in military barracks. ${ }^{15} \mathrm{We}$ also exclude a small proportion of American immigrants in Canada and Canadian immigrants in the U.S. ${ }^{16}$ While these are important demographic groups, they are not the focus of our study.

We study three outcomes: employment, annual hours worked, and hourly wage last year. In both datasets, employment is defined as equal to 1 if a respondent reported non-zero working hours in the past year, otherwise 0 . Annual total hours worked are constructed using the total hours of usually scheduled work from all jobs available in SLID. In SIPP, we multiply the usual hours worked in a week and weeks worked in that month. Hours worked in each month are summed to obtain annual hours worked. ${ }^{17}$ Observations with more than 4,000 annual hours worked are considered outliers and excluded from the analyses. ${ }^{18}$ We report results with log annual hours as the dependent variable and exclude observations with zero hours. ${ }^{19}$

In both datasets, hourly wage is derived by dividing annual earnings by the total usual hours worked in all jobs. ${ }^{20}$ Throughout the analysis, wage data are expressed in January 1996 prices using the Consumer Price Index for each country. In the wage analysis, observations with

because they often involve small sample sizes and we risk violating the disclosure rules of Statistics Canada.

${ }^{15}$ Our analysis includes the self-employed to offer a more complete picture. We conducted sensitivity analysis, dropping self-employed and found similar results for both men and women.

${ }^{16} 1,303$ person-year observations of U.S. immigrants in Canada in SLID and 876 person-year observations of Canadian immigrants in the U.S. in SIPP are excluded. We also did the analysis including immigrants from Canada to the US and immigrants from the US in Canada. The results were similar to those reported.

${ }^{17}$ We replace non-response months with average monthly hours worked in that year.

${ }^{18} 2,986$ person-year observations (1.4\% of the sample) in SLID and 3,976 person-year observations (1.1\%) in SIPP are excluded in hours worked models due to this restriction.

${ }^{19} \mathrm{We}$ also conducted similar analysis with hours worked as dependent variable assigning 0 hours worked to non-workers. Estimates were similar and can be obtained upon request.

${ }^{20}$ Total annual earnings in SIPP are derived by summing the monthly earnings in each year. We replace non-response months with the average of non-missing monthly earnings in that year. 
hourly wage more than U.S. $\$ 250$ or less than U.S. \$1 in the U.S. sample and more than Canadian dollar (CAD) $\$ 250$ or less than CAD \$1 in the Canadian sample are dropped. ${ }^{21}$

Both SLID and SIPP have data on immigrants' period of arrival, which are used to construct variables on years since immigration. In men's analysis, this variable is grouped into four categories: 0-5 years; 6-10 years; $11-20$ and $>20$ years, and in women's analysis, to avoid very small sized categories, the variable is grouped as: 0-10 years, 11-20 years, and $>20$ years since immigration. ${ }^{22}$ In addition, cohort of arrival is constructed into a set of dummy variables: arrived before 1970, arrived during 1970-1979, arrived during 1980-1989, and 1990 or later. Both data sources also provide information on immigrant's country/region of origin. We classify respondents into four categories: Africa and the Middle East, Asia, Latin America, and Europe (including Australia and New Zealand). Educational attainment is coded in four categories: less than high school, high school degree, some college or associate degree, and bachelor degree or above. Other demographics included in the regression analyses are: marital status at the end of each year, whether the respondent has a child under 18 living in the household, and state/province of residence.

Empirical analyses with longitudinal data suffer from attrition. Our two datasets, SIPP and SLID have comparable response and attrition rates. ${ }^{23} \mathrm{We}$ test if attrition influenced our

${ }^{21} 2,315$ person-year observations (1.2\%) in SLID and 2,622 person-year observations (1.0\%) in SIPP are excluded in hourly wage models due to the wage restriction. We also did the analysis by dropping the wage restriction and the results were similar to those with the restriction. ${ }^{22}$ In our Canadian wage sample, there are only 801 person year observations (266 individuals) of immigrant women in the $0-5$ years since immigration category.

${ }^{23}$ The initial response rate in the SIPP sample is $91.6 \%$ in the 1996 panel, $87 \%$ in the 2001 panel, and $85 \%$ in the 2004 panel. Including initial nonresponse and attrition, the cumulative sample loss was 35\% (over 12 waves) in 1996 panel, 31\% (over 9 waves) in 2001 panel, and 37\% (over 12 waves) in 2004 panel (National Research Council, 2009; US Census Bureau, 2008). By Wave 8, the rates of sample loss for the 1996, 2001, and 2004 panels were 31, 30 and $34 \%$, respectively (US Census Bureau, 2008). SLID has comparable response rates to SIPP. In 
results with two additional sets of analyses. ${ }^{24}$ First, we repeat our analysis using longitudinal weights and second, conduct additional analyses restricting samples to individuals who are present in all waves. The results from these analyses, presented in Appendix Tables 2 and 3 are qualitatively similar to those reported in the paper (based on respondents with at least two observations in each panel).

\section{Research Strategy}

Our objective is to study the trajectories of the labor market outcomes of immigrants at the two destinations using longitudinal data pooled across panels. We begin with a model as described in equation (1) estimated on a sample of nonelderly adults, aged 25 to 59 in the base year, separately for each country:

(1) $Y_{i t}=\alpha_{i 0}+X_{i t} B+\alpha_{1} * T_{t}+\alpha_{2} * I M M_{i} * T_{t}+\varepsilon_{i t}$ where $\mathrm{Y}_{\mathrm{it}}$ is one of the three labor market outcomes of individual $i$ in year $t$ (whether currently employed, log annual hours worked, or log hourly wage). The vector X denotes individual characteristics, namely educational attainment (education categories), whether currently married, and whether has children. Equation (1) includes a full set of individual fixed effects $\left(\alpha_{i 0}\right)$ that control for time-invariant individual characteristics including characteristics at arrival. The variable IMM is equal to 1 if the respondent is foreign-born, and 0 otherwise. $T_{t}$ is a trend variable denoting the number of years since the first interview and goes from 0 to 3 .

Panel 2 (beginning in 1996), the initial response rate was $89.5 \%$, which had fallen to $82.7 \%$ by the fourth year of the panel. Over time, the representativeness of each panel has diminished, such that by Panel 5 (starting in 2005), the initial response rate was $78.8 \%$, which fell to $72.8 \%$ by the fourth year of the panel. For details see: http://www23.statcan.gc.ca/imdbbmdi/document/3889 D13 T2 V2-eng.pdf. Table 5.2 p16.

${ }^{24}$ The distinction between sample attrition due to return migration, onward migration and attrition due to other reasons is important (see Aydemir \& Robinson, 2008). Unfortunately, our data do not provide information that would allow us to separate the cause of attrition. 
Economic assimilation is defined as the difference in annual earnings growth of immigrants and natives (convergence of earnings) (Borjas 1989, 1994). The coefficient on T captures the effect of age (experience and other time varying effects) and is restricted to be the same for immigrants and natives. The coefficient on IMM*T captures the YSI effect. ${ }^{25}$

The coefficients of interest are: $\alpha_{1}$ that estimates the average annual growth in the labor market outcome for native-born persons and $\alpha_{1}+\alpha_{2}$ that estimates the wage growth for immigrants; $\quad{ }_{2}$ is the coefficient of economic assimilation and captures the difference in annual growth of the labor market outcome of immigrants and natives. Further, to estimate if immigrant assimilation differs by immigrants' region of origin, the variable IMM is replaced by four dummy variables indicating immigrants' the region of origin: Asia, Europe, Africa and the Middle East, and Latin America. Because labor market experience differs by gender, all analyses are done separately for men and women. The use of person fixed effects is important as they control for unmeasured, person-specific factors that may be correlated with both selection of immigrants into different host countries (or length of stay in the host country) and immigrants' labor market outcomes (employment, hours worked, and wage).

Next, to estimate if immigrant economic assimilation differs by length of residence in the host country, a slightly modified version of equation (1), as follows, is estimated:

$$
\text { (2) } Y_{i t}=\beta_{i 0}+X_{i t} \Phi+\beta_{1} * T_{t}+\sum_{c} \beta_{2 c} * Y S I_{c} * T_{t}+e_{i t}
$$

There is one primary difference between Equations (1) and (2). In equation (2) the variable IMM is replaced with dummy variables YSI indicating years since immigration categories: 0-5 years, 6-10 years, 11-20 years and more than 20 years in the men's analysis; and 0-10 years, 11-

${ }^{25} \mathrm{We}$ did the analysis including age controls as dummy variables. The results were similar to those reported. This is expected. Our models include individual fixed effects. Therefore, only a small proportion of the sample report variation in age dummies across years. 
20 years, and $>20$ years in the women's analysis. ${ }^{26}$ Equation (2) also includes a full set of individual fixed effects, denoted by $\beta_{i 0}$.

Return migration may be selective on immigrant economic performance in the host country, which may bias labor market trajectories based on cross-sectional analysis (Ibarraran and Lubotsky, 2007, Kaushal, 2011). ${ }^{27}$ In a comparative analysis such bias may also occur if selectivity in return migration differs for migrants in Canada and the U.S. Our longitudinal approach yields estimates that describe how the earnings of immigrants change with time in the host country for the sample of immigrants who are present throughout the period of analysis. The use of person fixed effects will adjust for those unobserved and observed immigrant characteristics, e.g. characteristics at arrival, that have a time invariant influence on earnings. We acknowledge that the longitudinal sample is also affected by return migration (if people outmigrate between the waves). However, our longitudinal analysis will not be affected by the mechanical changes in sample composition across years-since-immigration categories due to return migration that has afflicted all research based on cross-sectional data. To determine the extent of bias in estimates based on cross-sectional data, we also compare the short-term trajectories of labor market outcomes from our longitudinal models with trajectories based on synthetic cohort models, described in detail below, that are commonly used in research based on Census data (e.g. Antecol et al, 2006).

\section{Results}

\section{Descriptive results}

\footnotetext{
${ }^{26}$ We do not include linear year since immigration variables because SIPP provide only aggregated information.

${ }^{27}$ Studies document many non-economic reasons for return migration (See Klinthall 2006, 2007, Masferrer and Roberts 2012, and Maron and Connell, 2008).
} 
Table 1 has descriptive statistics on foreign-born and native-born persons aged 25 to 59 in Canada and the U.S. in the base year (first observed year) of each panel. The immigrant sample is further restricted to persons who entered the host country after age 16. On average, immigrant men and women in Canada are four to five years older than immigrant men and women in the U.S., while the average ages of native men and women are roughly the same across the two countries. Immigrants in Canada are also more likely to be married. But while immigrant men in both countries are equally likely to have children, immigrant women in Canada are somewhat less likely to have children than immigrant women in the U.S.

As documented in previous research, immigrants in Canada are more educated than immigrants in the U.S. or the native born Canadian population: $31 \%$ of immigrant men and $28 \%$ immigrant women in the U.S. do not have a high-school degree - which is roughly double the corresponding proportions of high-school dropouts among immigrants in Canada; $63 \%$ of immigrant women and $66 \%$ of immigrant men in Canada have at least some college education, compared to less than half of immigrant men and women in the U.S. with college education. On the other hand, the U.S. born are somewhat more educated than men and women born in Canada. Immigrants in the two countries also differ markedly in terms of their regions of origin. Approximately $40 \%$ of immigrants in Canada are from Europe, Australia and New Zealand; in the U.S., the corresponding proportion from this region is $14 \%$. Over half the U.S. immigrant sample, compared to only $12 \%$ of the Canadian immigrant sample, is from Latin America; about $40 \%$ of the Canadian immigrant sample and a quarter of the U.S. immigrant sample is Asian; and 9\% of the Canadian sample and $7 \%$ of the U.S. immigrant sample are from Africa and the Middle East. 
In the U.S., immigrant men are somewhat more likely to be employed and immigrant women are somewhat less likely to be employed than immigrants of corresponding gender in Canada. Both immigrant and native-born workers in Canada are more than twice as likely to be covered by a union as immigrant and native workers in the U.S. Overall, workers in the U.S. work more hours than workers in Canada; and among U.S. workers the annual hours worked are greater for the U.S. born than the foreign-born. Despite their better educational credentials, the average wage of immigrant men in Canada is roughly the same as that of native-born men, and the average wage of immigrant women is about seven percent lower. The average wage of immigrant men in the U.S. is $18 \%$ lower than that of native men and the average wage of immigrant women is $10 \%$ lower than that of native women, which is expected given their relatively lower educational credentials.

\section{Multivariate Analysis}

\section{Employment and Hours Worked Trajectories of Immigrant Men}

We first present labor market trajectories of immigrant men. Table 2 presents estimates of the employment trajectories of men using longitudinal data. All models control for respondent's educational attainment, marital status, whether respondent has children under 18 in the household, and person fixed effects. Because the models include person fixed effects, all timeinvariant controls drop out. Model 1 estimates the average trajectory for all immigrants, Model 2 provides estimates by years-since-immigration, and Model 3 provides estimates by region of origin. ${ }^{28}$ The trend variable measures years since the first observed year of the panel.

\footnotetext{
${ }^{28}$ We evaluated how sample attrition may affect the results by comparing models based on respondents present in at least 2 waves and those present across all waves of the survey. The results are qualitatively similar (see Appendix Table 3), suggesting that attrition is not likely to seriously bias the results.
} 
The coefficient on the trend variable provides the average annual growth in employment among the native-born during the four years of the longitudinal study and the coefficient on the interaction term between foreign-born and trend estimates the difference in employment growth between the foreign-born and native-born. Note that we are not interested in the overall trajectories of labor market outcomes of immigrants in the two countries, but their rates of assimilation. The overall trajectory is a combination of two factors: economic conditions in the host country and immigrant relative performance. We are interested in the latter, which provides the relative growth in employment (or hours worked or real wage) of immigrants after controlling for the overall economic trend in the host country. ${ }^{29}$

Estimates show that native-born men in both countries experienced a decline in employment in the four years of the longitudinal study period. Immigrant men in Canada experienced the same trend as natives; immigrant men in the U.S., on the other hand, experienced a net growth over the native trend. Further analysis (Table 2, columns 3-6) shows that this difference in employment trajectories is on account of immigrants with a high-school or lower education, who saw a net growth in employment (over the native trend) in the U.S. but not in Canada. The employment trajectories of immigrants with more than a high-school degree are similar in both countries.

Employment growth varies by immigrants' YSI. In both countries, there is a net growth in employment among recent arrivals. Immigrant men in Canada with more than 20 YSI, on the other hand, experienced a 1.7 percentage-point annual decline in employment (over the native

\footnotetext{
${ }^{29}$ The last year of observation in the Canadian data is 2008 - the beginning of a recessionary period (the U.S. data covers through 2007 only). We conduct analysis excluding 2008 and find similar results for employment status and hourly wage for both the men's and women's analyses. The increase in hours worked for the $0-5$ year male cohort remains similar in magnitude but is reduced to non-significance.
} 
trend), perhaps due to early retirement. ${ }^{30}$ In the U.S., on the other hand, immigrant men in the country for more than 20 years defied the national trend of decline in male employment. There are some differences in the employment trajectories of immigrants from different regions of origin in the two countries. However, further analysis shows that the differences are largely confined to low-educated immigrants in the U.S., who experienced a higher growth in employment over the national trend (Table 2, column 5).

Table 3 presents estimates from models with log hours worked as the dependent variable. Overall results are similar to those in the employment analysis: on average there is a positive relative growth in hours worked among immigrant men in the U.S. (relative to U.S. natives), but not in Canada. Among recent immigrants, there is a positive relative growth in hours worked of immigrant men in both countries; immigrant men in Canada for more than 20 years also experienced a decline in hours worked during the study period.

To sum up, estimates based on person fixed effects models show that on average there is no evidence of additional growth in employment or hours worked of immigrant men (relative to Canadian-born men) in Canada, but positive annual growth on both outcomes of immigrant men (relative to U.S. born) in the U.S. Recent immigrant men in both countries experienced a relative positive growth in employment and hours worked, but there is evidence of a decline in employment and hours worked (relative to natives) among earlier arrivals in Canada. In Canada, there is generally not much difference in employment and hours worked growth of low- and high-educated immigrant men. In the U.S., on the other hand, employment growth is mostly

\footnotetext{
${ }^{30} \mathrm{We}$ further explored the decline in employment among earlier cohort of immigrants in Canada by stratifying the data based on age in the base year of the survey in two groups: men aged 25-42 and men aged 43-59. Our estimates indicate that the decline in employment is significant only for immigrant men aged 43-59.
} 
confined to the low-educated, especially for recent arrivals, but hours worked trajectories are approximately the same for the low- and high-educated.

\section{Wage Trajectories}

Our final outcome is $\log$ hourly wage. ${ }^{31}$ Estimates in Table 4 show that on average there is no wage assimilation experienced by immigrants in Canada. Immigrants in the U.S., on the other hand, experienced a $1.3 \%$ annual growth in real wage over the wage growth experienced by native men. Estimates in Model 2 show that assimilation continues for a longer period after arrival among immigrant men in the U.S. than among immigrant men in Canada. Immigrant men in Canada for 0-5 years experienced a $2.2 \%$ growth in hourly wage in addition to the wage growth of $2.2 \%$ experienced by native men, but there is no additional earnings growth for immigrant men living in Canada for more than 5 years. Immigrant men in the U.S. for 0-10 years experienced a $3 \%$ increase in wages in addition to the $1.2 \%$ wage growth experienced by all men, but most of the additional growth is due to male immigrants from Latin America, the most disadvantaged immigrant group in the U.S. (see e.g. Borjas, 2007). In Canada, on the other hand, estimates suggest no wage assimilation among immigrant men stratified by their country of origin.

The difference in wage assimilation between immigrants in the two countries is wider among the low-educated. In regressions for Canada, the coefficient on the interaction term between YSI categories and trend variables are mostly negative and always statistically

${ }^{31}$ The results in Tables 2 and 3 show that employment levels and hours worked (the coefficient on the trend variable) are decreasing throughout the sample period in both countries. This means that the composition of those that are working is also changing in these countries. To provide a complete picture, we present trajectories of employment, hours worked as well as wage. Note that our longitudinal analysis, unbalanced panel is based on respondents who are in the sample for at least two waves and balanced panel is based on respondents who are in the sample in all waves. Thus our analysis is less affected by the compositional changes than a corresponding analysis based on cross-sectional data. 
insignificant for low-educated men. In contrast, annual earnings assimilation (wage growth above the national trend) is between 3\% and 3.7\% for low-educated immigrant men during their first decade of U.S. residence. This could be because of the differences in the structures of labor market and welfare institutions in the two countries that incentivize faster economic assimilation in the U.S. and offer fewer incentives for employment and wage assimilation in Canada. ${ }^{32}$ Alternately, it may also be that due to a lower minimum wage in the U.S. (or the fact that many low-educated undocumented immigrants get paid less than the minimum wage), low-skilled immigrants in the U.S. have more catching up to do than low-skilled workers in Canada. However, our data show that low-skilled immigrant-native wage gaps (adjusted for age and family composition) are larger in Canada (23.7\%) than in the U.S. (18.9\%). The short-term earnings trajectories of recent high-educated (some college or more) immigrant men relative to natives in both countries are identical, but immigrants living in Canada for more than 20 years experience a negative assimilation, which is not the case for immigrants in the U.S.

Table 4 also shows that in the U.S. among men with more than a high school degree, those from Asia, Africa and the Middle-East have earning growth that is almost 2 percentage points higher than the earnings growth of the US born population, whereas high educated men from the two other sending regions -immigrants from Latin America and Europe - experienced the same wage growth as natives. Our research methodology does not provide any scientific explanation for this phenomenon. There may be certain other (unmeasured) attributes of immigrants from Asia, the Middle-East and Africa (e.g. occupation or industry specific-skills) that may cause this phenomenon.

\footnotetext{
${ }^{32}$ Immigrant and native outcomes may be differently affected by national policies due to a number of factors including immigrant eligibility and knowledge of these policies (or programs). Immigrants may also be culturally averse to utilizing welfare programs.
} 


\section{Women's Analysis}

Next, we estimate the labor market trajectories of immigrant women in the two countries. Most previous comparative research has focused on the labor market outcomes of immigrant men, partly because women are more likely than men to be family migrants rather than labor migrants. As such, immigrant women's labor market trajectories are thought to be linked to spouse's labor market assimilation and their own fertility choices, making it challenging to study their assimilation (Mincer, 1962; Schoeni, 1998). Trajectories of women’s labor market outcomes based on synthetic cohorts from cross-sectional data are especially troublesome as those are intertwined with differences in immigrant-native fertility patterns and labor force participation rates, which are both in turn shaped by the economic assimilation of men. Thus, estimates of immigrant women's assimilation are likely to confound with long-term trends in fertility and economic assimilation of immigrant men. The short-term trajectories based on longitudinal data suffer less from these biases even though they too are influenced by women's own fertility decisions and spouse's economic assimilation. In our analysis, we adjust for important time-varying determinants of women's employment such as whether the respondent is married or has children.

Estimates in Table 5, Model 1 suggest that overall there is little evidence of any relative growth in labor market outcomes among immigrant women in Canada (relative to women born in Canada). Whereas recent (in Canada for $<10$ years) immigrant women experienced growth in employment and hours worked (over the national trend), earlier arrivals experienced a modest negative assimilation on both domains. Lack of growth (or even negative growth) in hours worked is expected given that in the base year immigrant women in Canada worked more hours than women born in Canada (Table 1). 
Immigrant women in the U.S., on the other hand, experienced both (relative) employment growth and growth in hours worked, with the latter largely attributable to increased work effort by women from Latin America, Africa and the Middle East. There is some earnings assimilation of recently arrived immigrant women in the U.S., but not in Canada. In both countries, earlier arrivals (in the host country for more than 20 years) experienced a decline in earnings, which might be an indicator of limited long-term wage growth opportunities in the occupations (lowend service occupations) or locations (e.g. ethnic enclaves) where a majority of immigrant women work in the two countries. It is also possible that female earlier arrivals in both countries seek more flexible jobs with lower wages to take care of children or grandchildren. In general, while results are broadly similar on some dimensions to men's analysis, the cross-country difference seems to be smaller for women than for men.

\section{Comparison: Repeated Cross-sectional and Longitudinal Results}

Previous research in the U.S. and Canada has documented that cross-sectional synthetic cohort methodology over-estimates wage assimilation. Next, we present immigrant labor market trajectories using synthetic cohort methodology with multiple cross-sections of data (base years of each panel). Because previous U.S.-Canada comparative research that used a synthetic cohort methodology focused on immigrant men, for comparison, we restrict this analysis to the labor market outcomes of men and adopt models similar to Antecol et al. (2006). Our objective here is not to compare our findings with those of Antecol and colleagues, as their analysis pertained to immigrant labor market trajectories in the two countries during the eighties whereas we focus on a more recent period from 1996-2008. Our objective is to investigate how inferences drawn from the two analyses, cross-sectional synthetic cohort and longitudinal, differ. The results from the two analyses could differ simply because of the differences in methodologies or because the 
longitudinal analysis is based on three to four years of additional data on the actual trajectories of labor market outcomes of immigrants. ${ }^{33}$

Table 6 presents results from the cross-sectional analysis. All regressions control for age (dummy variable for age categories: 25-30, 31-35, 36-40, 41-45, 46-50, 51-55, 56-60, and 6164), education (four categories: less than high school, high school degree, some college or associate degree, and bachelor degree or above), state/province of residence (dummy variables for each state/province), year of observation (a dummy variable for each year), cohort of arrival (arrived before 1970, during 1970-1979, 1980-1989, 1990 or after (comparison category: US born), and years-since- immigration [0-5 years (comparison category), 6-10 years, 11-20 years, $>20$ years). For immigrants, the last three variables - year of observation, cohort of arrival, and years-since-immigration are collinear (Years-since-immigration=year of observation minus cohort of arrival). We address this issue by restricting the effect of year of observation to be the same for immigrants and natives. ${ }^{34}$ Further following previous research age and education effects are allowed to differ across years (of observation) by including interactions of year dummy variables and age category dummy variables and interactions of year dummy variables and education dummy variables (Antecol et al. 2006). While we present arrival cohort fixed effects, for brevity, we only discuss coefficients on the Years Since Immigration variables.

One question that arises is whether the trajectories estimated in Table 6 should be compared with the longitudinal trajectories that adjust for the national trend or with the

\footnotetext{
${ }^{33}$ We did the cross-sectional analysis with two samples: (i) all respondents in the first year and (ii) all respondents in year 1 who are present in at least 2 years. The results from these analyses were qualitatively similar.

${ }^{34}$ The issue of collinearity is also resolved as we include cohort of arrival and years-sinceimmigration as a set of dummy variables as indicated above rather than linear variables.
} 
unadjusted trajectories. Because Table 6 controls for arrival cohorts and year effects, we think the proper comparison is with the adjusted trajectories.

Table 6 shows that immigrant men in both countries experience slow and steady increases in employment with time in the host country and the trajectories are roughly the same in the two countries. In contrast, the short-term employment trajectories based on the longitudinal data suggest a non-linear trend in employment growth: recent immigrant men in both countries experience growth in employment (over the national trend); earlier arrivals experience a decline in employment in Canada and an increase in employment (over the national trend) in the U.S.

In both countries, the cross-sectional trajectories suggest a robust growth in hours worked in the first 10 years upon arrival, a somewhat modest but significant growth in the later years for immigrants in Canada, but not in the US. Longitudinal trajectories, on the other hand, suggest a positive growth for new arrivals in Canada, but there is little evidence of growth for earlier arrivals. Whereas point estimates suggest a higher growth in hours for recent immigrant men in the U.S., the growth remains statistically significant, albeit modest, for earlier arrivals as well.

Finally, adjusting for cohort of arrival, the cross-sectional analysis suggests that immigrant men in both countries experience a wage growth with one difference: for Canadian immigrants there is no wage growth in the first 20 years after arrival. This last finding also does not match with the results from our short-term wage trajectories based on longitudinal data, which show that wage growth among immigrant men in Canada is confined to recent immigrants (in Canada for less than 5 years).

\section{Conclusion}


We study the short-term trajectories of employment, hours worked, and real wages of immigrants in Canada and the U.S., using two nationally representative longitudinal datasets: the Canadian Survey of Labour and Income Dynamics (SLID) and the U.S. Survey of Income and Program Participation (SIPP) covering 1996-2008. We apply person fixed-effects models to control for time-invariant individual characteristics. To our knowledge, this is the first longitudinal comparative study of immigrant labor market assimilation in Canada and the U.S. and the first comparative study of immigrant women's labor market assimilation in the two countries.

Our analysis has three main findings: One, on average immigrant men (pooled across cohorts) in Canada do not experience significant relative growth in the three labor market outcomes compared to men born in Canada. Immigrant men in the U.S., by contrast, experience positive annual growth in all three domains relative to U.S. born men. Further analysis shows that this difference is largely driven by low-educated immigrant men, who experienced faster or longer duration of relative growth in all three outcomes in the U.S. than in Canada. We attribute this in part to the differences in the structures of labor market and welfare institutions in the two countries that incentivize or necessitate faster economic assimilation in the U.S. The earnings trajectories of recent high-educated immigrant men in both countries are identical, but higheducated immigrant men living in Canada for more than 20 years experience negative employment and wage assimilation, which is not the case for immigrants in the U.S. We think the last finding could also be related to some extent to Canada's more generous welfare system (employment and health insurance) that works to depress labor market engagement, especially for those getting close to retirement age. Indeed, estimates stratified by age suggest that the results are less robust for younger immigrants in Canada. 
Two, as expected, on all three domains, recent immigrant men in both countries experience some form of economic assimilation. However, the relative positive growth in employment, hours worked, and real wages begins to taper off for groups who have been in the host countries for a longer period, and in the case of Canadian immigrants there is evidence of early retirement among those who are in the country for more than 20 years. Our findings differ somewhat from Antecol et al. (2006), which used repeated cross-sections of data. They too concluded that immigrant men in both countries experienced positive earnings growth, and that U.S. immigrants experienced higher earnings assimilation than Canadian immigrants. But in their estimates, earnings growth remained robust for earlier arrivals, which is contrary to our finding. They also find that in the U.S. employment growth mostly happened in the first few years after arrival, but for Canadian immigrants it continued into later years as well, which is contrary to our finding. The difference in our findings could be on account of the difference in data and methodologies or due to the difference in period under study (they focus on the 1980s, whereas our study period is from 1996-2008).

We also estimated synthetic cohort models using multiple panels of SIPP and SLID data. Similar to Antecol et al., our cross-sectional analysis also shows that wage growth is robust for earlier arrivals in both countries, and in fact, for immigrants in Canada, the cross-sectional estimates suggest that almost all the wage growth is confined to immigrants who are in the country for at least 10 years (11-20 years and 20+ years). Comparing this with the short-term earnings trajectories based on longitudinal data leads us to conclude that the cross-sectional trajectories over-estimate the wage assimilation of earlier arrivals in both countries. Our findings are similar to those of previous research that have used longitudinal data in the U.S. (see e.g. Lubotsky, 2007). 
Finally, we find that recent immigrant women in the U.S. also experience economic assimilation on all three domains, and recent immigrant women in Canada experience economic assimilation in work effort - employment as well as hours worked, but not in wages. In both countries earlier arrivals (in the host country for more than 20 years) experienced a decline in relative earnings, which might be an indicator of limited long term wage growth opportunities in the occupations (low-end service occupations) or locations (e.g. ethnic enclaves) where a majority of immigrant women, especially the earlier arrivals, work in the two countries. It is also possible that earlier arrivals among immigrant women in both countries seek more flexible jobs that come with lower wages to take care of children or grandchildren.

To sum up, our estimates suggest a faster economic assimilation of immigrants in the U.S. than in Canada. The difference in immigrant labor market trajectories that we observe could be on account of the positive selection of immigrants to the U.S. (compared to Canada) in terms of unobserved attributes (after adjusting for observed attributes) or they could be due to differences in labor market and welfare institutions that, as we hypothesize, incentivize or necessitate greater labor market assimilation in the U.S. than in Canada. It could also be associated with the differences in immigration policies paired with country-specific labor market regulations. Observed outcomes for immigrants in these countries could also differ as a result of differences in macroeconomic conditions. In our paper, we include controls for native trajectories. But this is a potential source of difference if macroeconomic conditions affect immigrants and natives differently in the two countries. Further, differences in services provided to immigrants could be an additional source of difference in their trajectories.

We cannot definitively ascertain the mechanisms leading to the cross-country differences we observe because our data do not provide information required to draw such inferences. But 
our use of comparable longitudinal data does account for some potential sources of bias and is valuable in generating more rigorous and accurate estimates than studies relying on crosssectional data. Further research using richer data or qualitative approaches is needed to establish the mechanisms through which the cross-country difference is generated. 


\section{References}

Antecol, Heather, Kuhn, P., \& Trejo, S.J. (2006). Assimilation via prices or quantities? Sources of immigrant earnings growth in Australia, Canada, and the United States. Journal of Human Resources, 41, 821-840.

Aydemir, A., \& Robinson, C. (2008). Global labour markets, return, and onward migration. Canadian Journal of Ecnomics/Revue canadienne d'economique, 41(4), 1285-1311.

Aydemir, A., \& Skuterud, M. (2005). Explaining the deteriorating entry earnings of Canada's immigrant cohorts 1966-2000. Canadian Journal of Economics, 38, 641-672.

Aydemir, A., \& Skuterud, M., (2008). The immigrant wage differential within and across establishments. Industrial and Labor Relations Review, 61, 334-352.

Aydemir, A., \& Sweetman, A. (2008). First and Second Generation Immigrant Educational Attainment and Labor Market Outcomes: A Comparison of the United States and Canada. Research in Labor Economics, 27, 215-70.

Bagley, S. (2012). Provincial Nominee Programs: A Note on Policy Implications and Future Research Needs. Journal of International Migration and Integration, 13(1), 121-141.

Baker, M., \& Benjamin, D. (1994). The performance of immigrants in the Canadian labour market. Journal of Labour Economics, 12(3), 369-405.

Banerjee, R. (2009). Income growth of new immigrants in Canada: Evidence from the Survey of Labor and income Dynamics. Industrial Relations, 64(3), 466-488.

Beach, C., Green, A. G., \& Worswick, C. (2006). Impacts of the point system and immigration policy levers on skill characteristics of Canadian immigrants (Working Papers 1115). Kingston, Ontario: Queen's Department of Economics.

Beckhusen, J., Florax, R.J.G.M., Poot, J., \& Waldorf, B.S. (2013). Attracting global talent and then what? Overeducated immigrants in the United States. Journal of Regional Science, $53(5), 834-854$.

Beenstock, M. (2006). Longitudinal analysis of earnings assimilation among immigrants in Quebec. Unpublished paper, Hebrew University of Jerusalem.

Bloom, D. E., Grenier, G. \& Gunderson, M. (1995). The changing labour market position of Canadian immigrants. Canadian Journal of Economics, 28(4), 987-1005.

Bonikowska, A., Hou, F., \& Picot, G. (2011). A Canada-US Comparison of labour market outcomes among highly educated immigrants. Canadian Public Policy, 37, 25-48. 
Borjas, G. J. (1985). Changes in cohort quality, and the earnings of immigrants, Journal of Labor Economics, 3(4), 463-489.

Borjas, G. J. (1989). Immigrant and emigrant earnings: A longitudinal study. Economic Inquiry, 27, 21-37.

Borjas, G. (1994). The economics of immigration. Journal of Economic Literature, 32, 16671717.

Boyd, M. (2013). Accreditation and the labor market integration of internationally trained engineers and physicians in Canada. In T. Triadafilopoulos (Ed.), Wanted and Welcome? Policies for Highly Skilled Immigrants in Comparative Perspective (pp. 165-197). New York, NY: Springer.

Boyd, M. \& Thomas, D. (2002). Skilled immigrant labour: Country of origin and the occupational locations of male engineers. Canadian Studies in Population, 29(1), 7199.

Boyd, M. \& Schellenberg, G. (2007). Re-accreditation and the occupations of immigrant doctors and engineers. Canadian Social Trends, Fall, 2-10.

Chiswick, B. (1978). The effect of Americanization on the earnings of foreign-born men. Journal of Political Economy, 86, 897-921.

Chiswick, B., \& Miller, P.W. (2009). Educational mismatch: Are high-skilled immigrants really working at high-skilled jobs and the price they pay if they aren't? (IZA Discussion Paper 4280). Bonn, Germany: The Institute for the Study of Labor. Retrieved June 10, 2014, from http://ftp.iza.org/dp4280.pdf

Citizenship and Immigration Canada. (2013). Facts and figures 2013 - Immigration overview: Permanent residents. Retrieved from: http://www.cic.gc.ca/english/resources/statistics/facts2013/permanent/02.asp

Duleep, H. O., \& Dowhan, D. J. (2002). Insights from longitudinal data on the earnings growth of U.S. foreign-born men. Demography, 39, 485-506.

Frenette, M., \& Morissette, R. (2005). Will they ever converge? Earnings of immigrant and Canadian-born workers over the last two decades. International Migration Review, 39(1), $228-257$.

Girard, M., and Smith, M.R., (2013). Working in a regulated occupation in Canada: An immigrant—native born comparison. Journal of International Migration and Integration, 14(2), 219-244.

Government of Canada. (2010). Employment insurance regular benefits. Retrieved from: http://www.servicecanada.gc.ca/eng/ei/types/regular.shtml\#Number 
Government of Canada. (2014). Immigration overview: Permanent and temporary residents. Retrieved from: http://www.cic.gc.ca/english/resources/statistics/facts2010/permanent/01.asp.

Green, D., \& Worswick, C. (2009). Entry earnings of immigrant men in Canada: The roles of labour market entry effects and the returns to foreign experience. Retrieved from the University of British Columbia Vancouver School of Economics website: http://www.economics.ubc.ca/files/2013/05/pdf paper david-green-entry-earningsimmigrant-men.pdf

Hall, M., \& Farkas, G. (2008). Does Human Capital Raise Earnings for Immigrants in the LowSkill Labor Market? Demography, 45(3):619-639.

Hoefer, M., Rytina, N., \& Campbell, C. (2006). Estimates of the unauthorized immigrant population residing in the United States: January 2005. Retrieved from Office of Immigration Statistics, Policy Directorate, U.S. Department of Homeland Security: http://www.dhs.gov/xlibrary/assets/statistics/publications/ILL_PE_2005.pdf

$\mathrm{Hu}, \mathrm{W}$. (2000). Immigrant earnings assimilation: Estimates from longitudinal data. The American Economic Review, 90, 368-372.

Ibarraran, P., \& Lubotsky, D. (2007). Mexican Immigration and Self Selection: New Evidence from the 2000 Mexican Census, NBER Chapters, in: Mexican Immigration to the United States, (p. 159-192). National Bureau of Economic Research, Inc.

Kaushal, N. (2011). Earning trajectories of highly educated immigrants: Does place of education matter? Industrial \& Labor Relations Review, 64, 323-340.

Kaushal, N., \& Lu, Y. (2014). Recent immigration to Canada and the United States: A mixed tale of positive and negative relative selection, International Migration Review.

Kim, Seik. 2012. "Economic assimilation of foreign-born workers in the United States: An overlapping rotating panel analysis." Working paper, University of Washington.

Klinthäll, M. (2006). Retirement Return Migration from Sweden. International Migration, 44(2), 153-180.

Klinthäll, M. (2007). Refugee Return Migration: Return Migration from Sweden to Chile, Iran and Poland 1973-1996. The Journal of Refugee Studies, 20(4), 579-598.

Kuhn P. J., \& Riddell, C. (2010). The long-term effects of unemployment insurance: Evidence from New Brunswick and Maine, 1940-1991. Industrial and Labor Relations Review, 63, 183-204. 
Li, P. S. (2003). Initial earnings and catch-up capacity of immigrants. Canadian Public Policy / Analyse de Politiques, 29(3), 319-337.

Lubotsky, D. (2007). Chutes or ladders? A longitudinal analysis of immigrant earnings. Journal of Political Economy, 115, 820-867.

Maron, N., \& Connell, J. (2008). Back to Nukunuku: Employment, identity and return migration in Tonga. Asia Pacific Viewpoint, 49(2), 168-184.

Masferrer, C., \& Roberts, B. R. (2012). Going back home? Changing demography and geography of Mexican return migration. Population Research and Policy Review, 31(4), 465-496.

Mattoo, A., Meagu, I.C., Ozden, C. (2008). Brain waste? Educated immigrants in the US labor market. Journal of Development Economics, 87(2), 255-269.

McDonald, J.T., Warman, C., \& Worswick, C. (2012). Immigrant selection systems and occupational outcomes of international medical graduates in Canada and the United States (SEDAP Research Paper 293). Hamilton, ON: Social and Economic Dimensions of an Aging Population. Retrieved June 10, 2014, from http://socserv.mcmaster.ca/sedap/p/sedap293.pdf

National Research Council. (2009). Reengineering the Survey of Income and Program Participation. Panel on the Census Bureau's Reengineered Survey of Income and Program Participation, Constance F. Citro and John Karl Scholz, Editors. Committee on National Statistics, Division of Behavioral and Social Sciences and Education. Washington, DC: The National Academies Press.

Neumark, D., Salas, J. M. I., \& Wascher, W. (2013). Revisiting the minimum wage-employment debate: Throwing out the baby with the bathwater? (IZA Discussion Papers 7166). Bonn, Germany: Institute for the Study of Labor (IZA).

O’Connor, J. S., Orloff, A.S., \& Shaver, S. (1999). States, Markets, Families: Gender, Liberalism and Social Policy in Australia, Canada, Great Britain and the United States. Cambridge: Cambridge University Press.

Pandey, M., \& Townsend, J. (2011). Quantifying the Effects of the Provincial Nominee Programs. Canadian Public Policy, 37(4), 495-512.

Passel, J., \& Cohn, D. (2012). Unauthorized Immigrants: 11.1 Million in 2011. Washington, DC: Pew Research Center's Hispanic Trends Project.

Passel, J., \& Cohn, D. (2012) U.S. Foreign-Born Population: How Much Change from 2009 to 2010? Washington, DC: Pew Research Center's Hispanic Trends Project. 
Picot, G., \& Piraino, P. (2013). Immigrant earnings growth: selection bias or real progress? Canadian Journal of Economics, 46(4), 1510-1536.

Reitz, J. G. (2001). Immigrant skill utilization in the Canadian labour market: Implications of human capital research. Journal of International Migration and Integration/Revue de l'integration et de la migration internationale, 2(3), 347-378.

Schoeni, R. F. (1998). Labor market assimilation of immigrant women. Industrial and Labor Relations Review, 51(3), 483-504.

Statistics Canada. (2011). Immigration and Ethnocultural Diversity in Canada. Retrieved: http://www12.statcan.gc.ca/nhs-enm/2011/as-sa/99-010-x/99-010-x2011001-eng.pdf

Statistics Canada. (2012). Survey of Labour and Income Dynamics (SLID) - A Survey Overview. Document 75F0011X. Retrieved: http://www.statcan.gc.ca/pub/75f0011x/75f0011x2013001-eng.htm

Sweetman, A., \&Warman, C. (2010). "How Far Does the Points System Stretch? The Spouses of Skilled Worker Principal Applicants" in Canadian Immigration: Economic Evidence for a Dynamic Policy Environment, Ted McDonald, Elizabeth Ruddick, Arthur Sweetman, and Christopher Worswick (eds). Kingston: McGill-Queen's University Press; 183-207.

U.S. Census Bureau. (2008). SIPP User's Guide: Chapter 6 Nonsampling errors. Retrieved: http://www.census.gov/content/dam/Census/programssurveys/sipp/methodology/SIPP USERS Guide Chapter6 2008.pdf

U.S. Census Bureau. (2015a). American Fact Finder. Retrieved: http://factfinder.census.gov/faces/tableservices/jsf/pages/productview.xhtml?pid=ACS 1 3_3YR_S0201\&prodType $=$ table

U.S. Census Bureau. (2015b). SIPP Introduction and History. Retrieved: http://www.census.gov/programs-surveys/sipp/about/sipp-introduction-history.html

U.S. Department of Labor. (2013). State unemployment insurance benefits. Washington, D.C. Retrieved from: http://workforcesecurity.doleta.gov/unemploy/uifactsheet.asp.

U.S. Department of Homeland Security. (2013). Yearbook of Immigration Statistics: 2012. Washington, D.C. Retrieved from: http://www.dhs.gov/publication/yearbook-2012

U.S. Department of Homeland Security. (2014). Yearbook of Immigration Statistics. Washington, D.C. Retrieved from: https://www.dhs.gov/yearbook-immigration-statistics.

Wald, S., and T. Fang. (2008). Overeducated immigrants in the Canadian labour market: evidence from the workplace and employee survey. Canadian Pubic Policy, 34(4), 457480. 
Warman, C. (2007). Ethnic enclaves and immigrant earnings growth. Canadian Journal of Economics, 40(2), 401-422.

Warman, C. R., \& Worswick, C. (2004). Immigrant earnings performance in Canadian cities: 1981 through 2001. Canadian Journal of Urban Research, 13(1), 62-84 
Table 1: Descriptive Statistics

\begin{tabular}{|c|c|c|c|c|c|c|c|c|}
\hline & \multicolumn{4}{|l|}{ Men } & \multicolumn{4}{|l|}{ Women } \\
\hline & Canada-born & $\begin{array}{l}\text { Foreign-born } \\
\text { in Canada }\end{array}$ & US-born & $\begin{array}{l}\text { Foreign-born } \\
\text { in U.S. }\end{array}$ & Canada-born & $\begin{array}{l}\text { Foreign-born } \\
\text { in Canada }\end{array}$ & US-born & $\begin{array}{l}\text { Foreign-born } \\
\text { in U.S. }\end{array}$ \\
\hline \multicolumn{9}{|l|}{ Demographics } \\
\hline Age & 41.63 & 44.90 & 41.11 & 39.54 & 41.27 & 44.23 & 41.02 & 40.48 \\
\hline Married & 0.66 & 0.86 & 0.66 & 0.67 & 0.65 & 0.78 & 0.60 & 0.65 \\
\hline Has children $<18$ in household & 0.50 & 0.55 & 0.45 & 0.53 & 0.51 & 0.53 & 0.50 & 0.57 \\
\hline \multicolumn{9}{|l|}{ Education } \\
\hline$<$ High-school & 0.18 & 0.15 & 0.08 & 0.31 & 0.12 & 0.17 & 0.07 & 0.28 \\
\hline High School & 0.19 & 0.18 & 0.30 & 0.23 & 0.19 & 0.20 & 0.29 & 0.23 \\
\hline Some college & 0.47 & 0.39 & 0.33 & 0.19 & 0.51 & 0.40 & 0.36 & 0.22 \\
\hline BA or higher & 0.16 & 0.27 & 0.29 & 0.27 & 0.18 & 0.23 & 0.29 & 0.27 \\
\hline \multicolumn{9}{|l|}{ Labor market Characteristics } \\
\hline Currently employed & 0.91 & 0.91 & 0.92 & 0.94 & 0.79 & 0.72 & 0.81 & 0.69 \\
\hline Self-employed & 0.16 & 0.19 & 0.18 & 0.16 & 0.09 & 0.13 & 0.11 & 0.13 \\
\hline Covered by union & 0.41 & 0.33 & 0.19 & 0.13 & 0.39 & 0.31 & 0.15 & 0.13 \\
\hline Annual Hours Worked & 2111 & 2097 & 2265 & 2156 & 1664 & 1733 & 1847 & 1713 \\
\hline Real Hourly wage & 19.84 & 19.74 & 16.37 & 13.45 & 15.63 & 14.49 & 11.76 & 10.56 \\
\hline \multicolumn{9}{|l|}{ Region of Origin } \\
\hline Europe & & 0.42 & & 0.14 & & 0.39 & & 0.14 \\
\hline Latin America & & 0.11 & & 0.55 & & 0.12 & & 0.52 \\
\hline Africa \& Middle East & & 0.10 & & 0.07 & & 0.07 & & 0.06 \\
\hline Asia & & 0.37 & & 0.24 & & 0.42 & & 0.28 \\
\hline $\mathrm{N}$ & 21718 & 1802 & 49662 & 7132 & 20630 & 1698 & 48779 & 5894 \\
\hline
\end{tabular}

Notes: Descriptive statistics are for individuals aged 25-59 in their first wave of each panel and not enrolled in school during the reference year in the Survey of Labour and Income Dynamics for Canada, and the Survey of Income and Program Participation in the United States. Immigrants arriving before the age of 17 and immigrants from the U.S. to Canada and from Canada to the U.S. are excluded from the sample. N corresponds to number of individuals in their first observed year of the hourly wage models. Real hourly wage is expressed in January 1996 U.S. dollar for the U.S. data and January 1996 Canadian dollar for the Canadian data. Hours worked and current employment status are calculated on the analytic samples from the employment and hours worked models. 
Table 2: Estimates of Annual Growth in Employment of Native-born and Immigrant Men in Canada and the U.S. (Models using longitudinal data with individual fixed effects)

\begin{tabular}{|c|c|c|c|c|c|c|}
\hline & Canada & U.S. & Canada & & US & \\
\hline Model 1 & & & $\begin{array}{l}\text { High-School or } \\
\text { less }\end{array}$ & $\begin{array}{l}\text { More than } \\
\text { High-school }\end{array}$ & $\begin{array}{l}\text { High-School or } \\
\text { less }\end{array}$ & $\begin{array}{l}\text { More than } \\
\text { High-school }\end{array}$ \\
\hline $\begin{array}{l}\text { Trend } \\
\text { Foreign-born*trend }\end{array}$ & $\begin{array}{l}-0.008 * * \\
(0.000) \\
-0.002 \\
(0.002)\end{array}$ & $\begin{array}{l}-0.010 * * \\
(0.000) \\
0.005 * * \\
(0.001)\end{array}$ & $\begin{array}{l}-0.010 * * \\
(0.001) \\
-0.002 \\
(0.003)\end{array}$ & $\begin{array}{l}-0.007 * * \\
(0.001) \\
-0.002 \\
(0.002)\end{array}$ & $\begin{array}{l}-0.013^{* *} \\
(0.001) \\
0.009 * * \\
(0.002)\end{array}$ & $\begin{array}{l}-0.008 * * \\
(0.000) \\
0.001 \\
(0.001)\end{array}$ \\
\hline Model 2 & & & & & & \\
\hline Trend & $\begin{array}{l}-0.008 * * \\
(0.000)\end{array}$ & $\begin{array}{l}-0.010 * * \\
(0.000)\end{array}$ & $\begin{array}{l}-0.010 * * \\
(0.001)\end{array}$ & $\begin{array}{l}-0.007 * * \\
(0.001)\end{array}$ & $\begin{array}{l}-0.013^{* *} \\
(0.001)\end{array}$ & $\begin{array}{l}-0.008 * * \\
(0.000)\end{array}$ \\
\hline $\mathrm{YSI}=0-5 \mathrm{yrs} *$ trend & $\begin{array}{l}0.014 * * \\
(0.004)\end{array}$ & $\begin{array}{l}0.010 * * \\
(0.003)\end{array}$ & $\begin{array}{l}0.013 \\
(0.009)\end{array}$ & $\begin{array}{l}0.014 * * \\
(0.005)\end{array}$ & $\begin{array}{l}0.015^{* *} \\
(0.005)\end{array}$ & $\begin{array}{l}0.006 \dagger \\
(0.003)\end{array}$ \\
\hline YSI $=6-10 \mathrm{yrs} *$ trend & $\begin{array}{l}0.010^{*} \\
(0.004)\end{array}$ & $\begin{array}{l}0.003 \\
(0.003)\end{array}$ & $\begin{array}{l}0.014 \dagger \\
(0.008)\end{array}$ & $\begin{array}{l}0.008 \dagger \\
(0.005)\end{array}$ & $\begin{array}{l}0.008 * \\
(0.004)\end{array}$ & $\begin{array}{l}-0.002 \\
(0.003)\end{array}$ \\
\hline YSI $=11-20 \mathrm{yrs}^{*}$ trend & $\begin{array}{l}0.002 \\
(0.003)\end{array}$ & $\begin{array}{l}0.004 \dagger \\
(0.002)\end{array}$ & $\begin{array}{l}0.013^{*} \\
(0.006)\end{array}$ & $\begin{array}{l}-0.005 \\
(0.004)\end{array}$ & $\begin{array}{l}0.006 \dagger \\
(0.003)\end{array}$ & $\begin{array}{l}0.004 \\
(0.003)\end{array}$ \\
\hline YSI $>20 \mathrm{yrs} *$ trend & $\begin{array}{l}-0.017 * * \\
(0.003)\end{array}$ & $\begin{array}{l}0.007 * \\
(0.003)\end{array}$ & $\begin{array}{l}-0.024 * * \\
(0.005)\end{array}$ & $\begin{array}{l}-0.013^{* *} \\
(0.003)\end{array}$ & $\begin{array}{l}0.010 * \\
(0.005)\end{array}$ & $\begin{array}{l}0.006 \\
(0.004)\end{array}$ \\
\hline Model 3 & & & & & & \\
\hline Trend & $\begin{array}{l}-0.008 * * \\
(0.001)\end{array}$ & $\begin{array}{l}-0.010 * * \\
(0.000)\end{array}$ & $\begin{array}{l}-0.010 * * \\
(0.001)\end{array}$ & $\begin{array}{l}-0.007 * * \\
(0.001)\end{array}$ & $\begin{array}{l}-0.013^{* *} \\
(0.001)\end{array}$ & $\begin{array}{l}-0.008 * * \\
(0.000)\end{array}$ \\
\hline Europe*trend & $\begin{array}{l}-0.007 * * \\
(0.003)\end{array}$ & $\begin{array}{l}0.006 \dagger \\
(0.003)\end{array}$ & $\begin{array}{l}-0.008 \\
(0.005)\end{array}$ & $\begin{array}{l}-0.007 * \\
(0.003)\end{array}$ & $\begin{array}{l}0.013^{*} \\
(0.006)\end{array}$ & $\begin{array}{l}0.002 \\
(0.003)\end{array}$ \\
\hline Latin America*trend & $\begin{array}{l}-0.008 \\
(0.005)\end{array}$ & $\begin{array}{l}0.003 \\
(0.002)\end{array}$ & $\begin{array}{l}-0.008 \\
(0.009)\end{array}$ & $\begin{array}{l}-0.008 \\
(0.006)\end{array}$ & $\begin{array}{l}0.006 * * \\
(0.002)\end{array}$ & $\begin{array}{l}0.001 \\
(0.003)\end{array}$ \\
\hline Africa \& Middle East*trend & $\begin{array}{l}0.010 \dagger \\
(0.005)\end{array}$ & $\begin{array}{l}-0.000 \\
(0.005)\end{array}$ & $\begin{array}{l}0.019 \dagger \\
(0.011)\end{array}$ & $\begin{array}{l}0.006 \\
(0.006)\end{array}$ & $\begin{array}{l}0.016 \\
(0.011)\end{array}$ & $\begin{array}{l}-0.006 \\
(0.005)\end{array}$ \\
\hline Asia*trend & $\begin{array}{l}0.003 \\
(0.003)\end{array}$ & $\begin{array}{l}0.008 * * \\
(0.002)\end{array}$ & $\begin{array}{l}0.003 \\
(0.005)\end{array}$ & $\begin{array}{l}0.003 \\
(0.003)\end{array}$ & $\begin{array}{l}0.016^{* *} \\
(0.005)\end{array}$ & $\begin{array}{l}0.004 \dagger \\
(0.002)\end{array}$ \\
\hline $\mathrm{N}$ & 95531 & 170685 & 37581 & 57950 & 71915 & 98770 \\
\hline
\end{tabular}

Notes: The sample of analysis is individuals aged 25-59 (in their first wave), not enrolled in school, and responded to the survey in two or more years. Immigrants who arrived before age 17, immigrants from the U.S. to Canada and from Canada to the U.S. are excluded. Employment status is coded as 1 if a respondent reports more than 0 hours worked in a year, otherwise 0 . Figures in each cell are estimated coefficients on the variables listed as row headings. Coefficients in each model of each column are from a separate regression. All models control for education, marital status, whether the respondent has children under 18 in the household, and individual fixed effects.

$* * \mathrm{p} \leq .01, *$ for $0.01<\mathrm{p} \leq .05$, and $\dagger$ for $0.05<\mathrm{p} \leq .1$. 
Table 3: Estimates of Annual Growth in Log Annual Hours Worked of Native-born and Immigrant Men in Canada and the U.S. (Models using longitudinal data with individual fixed effects)

\begin{tabular}{|c|c|c|c|c|c|c|}
\hline \multirow{3}{*}{$\begin{array}{l}\text { Model } 1 \\
\text { Trend } \\
\text { Foreign-born*trend }\end{array}$} & \multirow{3}{*}{$\begin{array}{l}\text { Canada } \\
\\
-0.010^{* *} \\
(0.001) \\
0.004 \\
(0.005)\end{array}$} & \multirow{3}{*}{$\begin{array}{l}\text { U.S. } \\
\\
-0.015^{* *} \\
(0.001) \\
0.019^{* *} \\
(0.003)\end{array}$} & \multicolumn{2}{|l|}{ Canada } & \multicolumn{2}{|l|}{ US } \\
\hline & & & $\begin{array}{l}\text { High-School } \\
\text { or less }\end{array}$ & $\begin{array}{l}\text { More than } \\
\text { High-school }\end{array}$ & $\begin{array}{l}\text { High-School } \\
\text { or less }\end{array}$ & $\begin{array}{l}\text { More than } \\
\text { High-school }\end{array}$ \\
\hline & & & $\begin{array}{l}-0.006^{* *} \\
(0.002) \\
-0.000 \\
(0.009)\end{array}$ & $\begin{array}{l}-0.011 * * \\
(0.002) \\
0.006 \\
(0.005)\end{array}$ & $\begin{array}{l}-0.017 * * \\
(0.002) \\
0.022 * * \\
(0.004)\end{array}$ & $\begin{array}{l}-0.015 * * \\
(0.001) \\
0.015 * * \\
(0.004)\end{array}$ \\
\hline Model 2 & & & & & & \\
\hline Trend & $\begin{array}{l}-0.010 * * \\
(0.001)\end{array}$ & $\begin{array}{l}-0.015^{*} \\
(0.001)\end{array}$ & $\begin{array}{l}-0.006 * * \\
(0.002)\end{array}$ & $\begin{array}{l}-0.011 * * \\
(0.002)\end{array}$ & $\begin{array}{l}-0.017 * \\
(0.002)\end{array}$ & $\begin{array}{l}-0.015 * * \\
(0.001)\end{array}$ \\
\hline YSI $=0-5$ yrs $*$ trend & $\begin{array}{l}0.024 * \\
(0.011)\end{array}$ & $\begin{array}{l}0.048 * * \\
(0.006)\end{array}$ & $\begin{array}{l}0.015 \\
(0.024)\end{array}$ & $\begin{array}{l}0.028^{*} \\
(0.012)\end{array}$ & $\begin{array}{l}0.056^{* *} \\
(0.010)\end{array}$ & $\begin{array}{l}0.039 * * \\
(0.008)\end{array}$ \\
\hline $\mathrm{YSI}=6-10 \mathrm{yrs} *$ trend & $\begin{array}{l}0.009 \\
(0.010)\end{array}$ & $\begin{array}{l}0.013 * \\
(0.006)\end{array}$ & $\begin{array}{l}0.010 \\
(0.019)\end{array}$ & $\begin{array}{l}0.008 \\
(0.012)\end{array}$ & $\begin{array}{l}0.011 \\
(0.009)\end{array}$ & $\begin{array}{l}0.017 * \\
(0.008)\end{array}$ \\
\hline YSI $=11-20 \mathrm{yrs}^{*}$ trend & $\begin{array}{l}0.010 \\
(0.008)\end{array}$ & $\begin{array}{l}0.007 \\
(0.005)\end{array}$ & $\begin{array}{l}0.011 \\
(0.015)\end{array}$ & $\begin{array}{l}0.009 \\
(0.010)\end{array}$ & $\begin{array}{l}0.003 \\
(0.007)\end{array}$ & $\begin{array}{l}0.014^{*} \\
(0.007)\end{array}$ \\
\hline YSI $>20 \mathrm{yrs} *$ trend & $\begin{array}{l}-0.013 \dagger \\
(0.008)\end{array}$ & $\begin{array}{l}0.009 \\
(0.007)\end{array}$ & $\begin{array}{l}-0.019 \\
(0.014)\end{array}$ & $\begin{array}{l}-0.010 \\
(0.009)\end{array}$ & $\begin{array}{l}0.018 \dagger \\
(0.011)\end{array}$ & $\begin{array}{l}-0.002 \\
(0.010)\end{array}$ \\
\hline Model 3 & & & & & & \\
\hline Trend & $\begin{array}{l}-0.010 * * \\
(0.001)\end{array}$ & $\begin{array}{l}-0.015^{*} \\
(0.001)\end{array}$ & $\begin{array}{l}-0.006^{* *} \\
(0.002)\end{array}$ & $\begin{array}{l}-0.011 * * \\
(0.002)\end{array}$ & $\begin{array}{l}-0.016^{*} \\
(0.002)\end{array}$ & $\begin{array}{l}-0.015 * * \\
(0.001)\end{array}$ \\
\hline Europe*trend & $\begin{array}{l}0.004 \\
(0.007)\end{array}$ & $\begin{array}{l}0.013 \dagger \\
(0.007)\end{array}$ & $\begin{array}{l}0.004 \\
(0.013)\end{array}$ & $\begin{array}{l}0.005 \\
(0.008)\end{array}$ & $\begin{array}{l}0.020 * * \\
(0.005)\end{array}$ & $\begin{array}{l}0.012 \\
(0.008)\end{array}$ \\
\hline Latin America*trend & $\begin{array}{l}-0.000 \\
(0.014)\end{array}$ & $\begin{array}{l}0.018 * * \\
(0.004)\end{array}$ & $\begin{array}{l}-0.010 \\
(0.023)\end{array}$ & $\begin{array}{l}0.005 \\
(0.017)\end{array}$ & $\begin{array}{l}0.040 \dagger \\
(0.024)\end{array}$ & $\begin{array}{l}0.016 * \\
(0.007)\end{array}$ \\
\hline Africa \& Middle East*trend & $\begin{array}{l}0.007 \\
(0.015)\end{array}$ & $\begin{array}{l}0.036^{* *} \\
(0.011)\end{array}$ & $\begin{array}{l}0.016 \\
(0.031)\end{array}$ & $\begin{array}{l}0.006 \\
(0.016)\end{array}$ & $\begin{array}{l}0.025^{*} \\
(0.011)\end{array}$ & $\begin{array}{l}0.032 * * \\
(0.011)\end{array}$ \\
\hline Asia*trend & $\begin{array}{l}0.004 \\
(0.007)\end{array}$ & $\begin{array}{l}0.015 * * \\
(0.005)\end{array}$ & $\begin{array}{l}-0.005 \\
(0.014)\end{array}$ & $\begin{array}{l}0.009 \\
(0.009)\end{array}$ & $\begin{array}{l}0.020 * * \\
(0.005)\end{array}$ & $\begin{array}{l}0.012 * \\
(0.006)\end{array}$ \\
\hline $\mathrm{N}$ & 82579 & 150152 & 30665 & 51914 & 60049 & 90103 \\
\hline
\end{tabular}

Notes: See notes to Table 2. ** $\mathrm{p} \leq .01, *$ for $0.01<\mathrm{p} \leq .05$, and $\dagger$ for $0.05<\mathrm{p} \leq .1$. 
Table 4: Estimates of Wage Growth (Log Real Hourly Wage) of Native-born and Immigrant Men in Canada and the US (Models using longitudinal data with individual fixed effects)

\begin{tabular}{|c|c|c|c|c|c|c|}
\hline & Canada & U.S. & \multicolumn{2}{|l|}{ Canada } & \multicolumn{2}{|l|}{ US } \\
\hline \multirow[t]{2}{*}{ Model 1} & \multirow[b]{2}{*}{$\begin{array}{l}0.022 * * \\
(0.001)\end{array}$} & \multirow[b]{2}{*}{$\begin{array}{l}0.012 * * \\
(0.001)\end{array}$} & $\begin{array}{l}\text { High-School } \\
\text { or less }\end{array}$ & $\begin{array}{l}\text { More than } \\
\text { High-school }\end{array}$ & $\begin{array}{l}\text { High-School } \\
\text { or less }\end{array}$ & $\begin{array}{l}\text { More than } \\
\text { High-school }\end{array}$ \\
\hline & & & $0.013 * *$ & $0.028 * *$ & $0.016^{* *}$ & $0.010 * *$ \\
\hline Foreign-born*trend & $\begin{array}{l}-0.002 \\
(0.005)\end{array}$ & $\begin{array}{l}0.013 * * \\
(0.003)\end{array}$ & $\begin{array}{l}(0.002) \\
-0.001 \\
(0.008)\end{array}$ & $\begin{array}{l}(0.002) \\
-0.003 \\
(0.005)\end{array}$ & $\begin{array}{l}0.012 * \\
(0.005)\end{array}$ & $\begin{array}{l}0.011 * \\
(0.005)\end{array}$ \\
\hline \multicolumn{7}{|l|}{ Model 2} \\
\hline Trend & $0.022 * *$ & $0.012 * *$ & $0.013 * *$ & $0.028 * *$ & $0.016^{*}$ & $0.010 * *$ \\
\hline \multirow{2}{*}{ YSI $=0-5$ yrs $*$ trend } & $\begin{array}{l}(0.001) \\
0.022 *\end{array}$ & $\begin{array}{l}(0.001) \\
0.030 * *\end{array}$ & $\begin{array}{l}(0.002) \\
-0.004\end{array}$ & $\begin{array}{l}(0.002) \\
0.025 *\end{array}$ & $\begin{array}{l}(0.002) \\
0.030 * *\end{array}$ & $\begin{array}{l}(0.001) \\
0.029 * *\end{array}$ \\
\hline & $(0.011)$ & $(0.008)$ & $(0.024)$ & $(0.012)$ & $(0.011)$ & $(0.011)$ \\
\hline \multirow[t]{2}{*}{$\mathrm{YSI}=6-10 \mathrm{yrs} *$ trend } & 0.006 & $0.030 * *$ & -0.000 & 0.008 & $0.037 * *$ & $0.018 \dagger$ \\
\hline & $(0.010)$ & $(0.007)$ & $(0.019)$ & $(0.012)$ & $(0.010)$ & $(0.011)$ \\
\hline YSI $=11-20 \mathrm{yrs}^{*}$ trend & $\begin{array}{l}-0.006 \\
(0.008)\end{array}$ & $\begin{array}{l}0.003 \\
(0.006)\end{array}$ & $\begin{array}{l}-0.013 \\
(0.015)\end{array}$ & $\begin{array}{l}-0.002 \\
(0.010)\end{array}$ & $\begin{array}{l}0.006 \\
(0.008)\end{array}$ & $\begin{array}{l}-0.005 \\
(0.009)\end{array}$ \\
\hline YSI $>20$ yrs $*$ trend & $\begin{array}{l}-0.015^{*} \\
(0.008)\end{array}$ & $\begin{array}{l}0.006 \\
(0.009)\end{array}$ & $\begin{array}{l}0.009 \\
(0.013)\end{array}$ & $\begin{array}{l}-0.029 * * \\
(0.009)\end{array}$ & $\begin{array}{l}-0.005 \\
(0.012)\end{array}$ & $\begin{array}{l}0.017 \\
(0.013)\end{array}$ \\
\hline \multicolumn{7}{|l|}{ Model 3} \\
\hline Trend & $0.022 * *$ & $\begin{array}{l}0.012 * * \\
(0,001)\end{array}$ & $\begin{array}{l}0.013 * * \\
(0.002)\end{array}$ & $0.028 * *$ & $0.016 *$ & $0.017 \dagger$ \\
\hline \multirow{2}{*}{ Europe*trend } & -0.008 & $\begin{array}{l}(0.001) \\
0.008\end{array}$ & $\begin{array}{l}(0.002) \\
-0.005\end{array}$ & $\begin{array}{l}(0.002) \\
-0.010\end{array}$ & $\begin{array}{l}(0.002) \\
-0.012\end{array}$ & $\begin{array}{l}(0.010) \\
0.010\end{array}$ \\
\hline & $(0.007)$ & $(0.009)$ & $(0.013)$ & $(0.008)$ & $(0.016)$ & $(0.009)$ \\
\hline \multirow[t]{2}{*}{ Latin America*trend } & -0.003 & $0.018 * *$ & 0.012 & -0.012 & $0.017 * *$ & 0.002 \\
\hline & $(0.014)$ & $(0.004)$ & $(0.022)$ & $(0.017)$ & $(0.005)$ & $(0.015)$ \\
\hline \multirow[t]{2}{*}{ Africa \& Middle East*trend } & -0.009 & 0.009 & -0.038 & -0.002 & 0.031 & $0.019 *$ \\
\hline & $(0.014)$ & $(0.013)$ & $(0.030)$ & $(0.016)$ & $(0.027)$ & $(0.008)$ \\
\hline \multirow[t]{2}{*}{ Asia*trend } & 0.006 & 0.010 & 0.006 & 0.005 & -0.009 & $0.017 \dagger$ \\
\hline & $(0.007)$ & $(0.007)$ & $(0.014)$ & $(0.009)$ & $(0.012)$ & $(0.010)$ \\
\hline $\mathrm{N}$ & 79565 & 147172 & 29392 & 50173 & 58664 & 88508 \\
\hline
\end{tabular}

Notes: see notes to Table 2 . The dependent variable is logged annual hourly real wage.

$* * \mathrm{p} \leq .01, *$ for $0.01<\mathrm{p} \leq .05$, and $\dagger$ for $0.05<\mathrm{p} \leq .1$. 
Table 5: Estimates of Annual Growth in Employment, Log Annual Hours Worked and Real Wage (Log Real Wage) of Native-born and Immigrant Women in Canada and the U.S. (Models using longitudinal data with individual fixed effects)

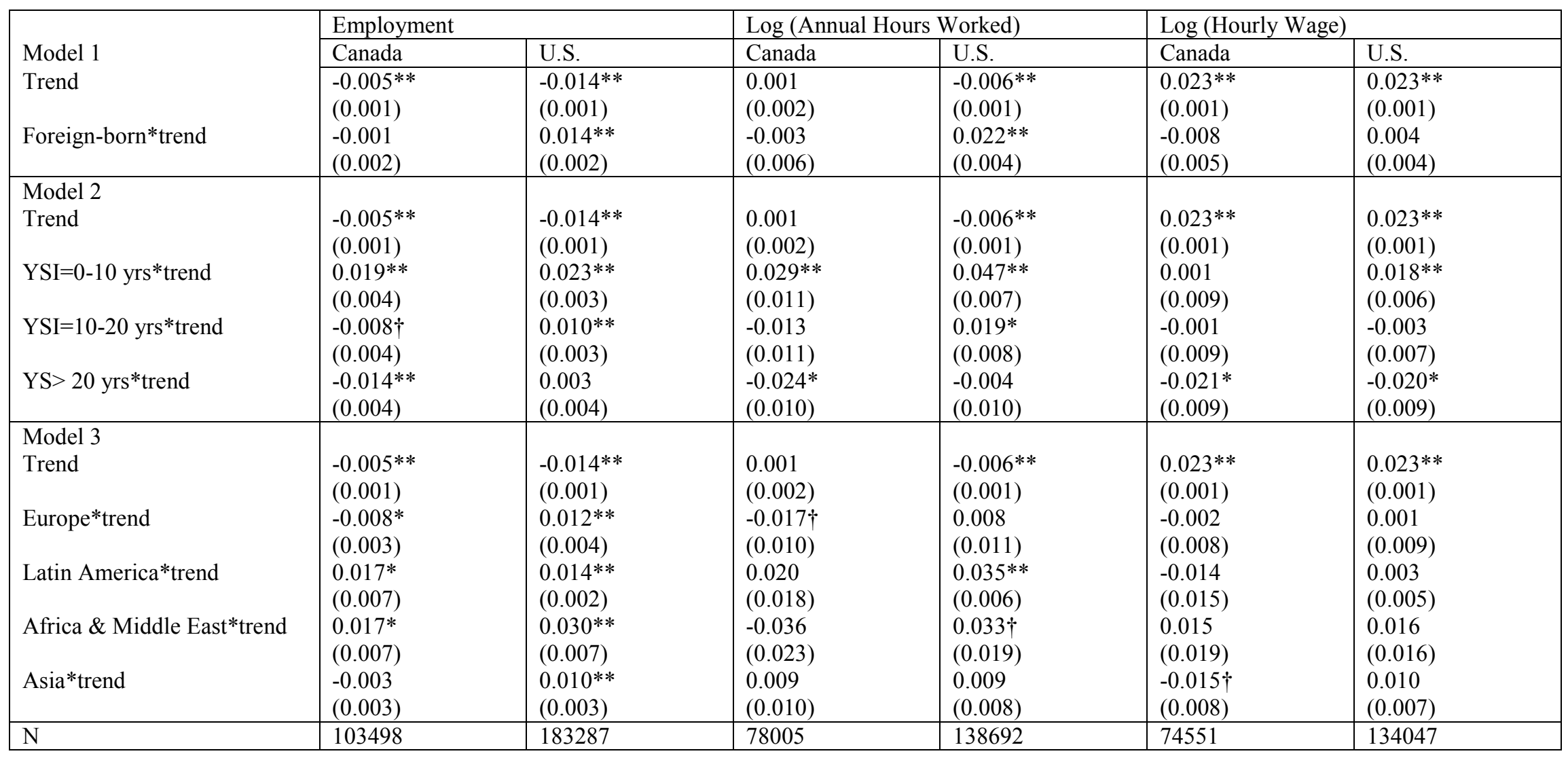

See Notes to Tables 2

$* * \mathrm{p} \leq .01, *$ for $0.01<\mathrm{p} \leq .05$, and $\dagger$ for $0.05<\mathrm{p} \leq .1$. 
Table 6: Estimated Trajectories of Employment, Log Hours Worked and Log Wage of Immigrant Men in Canada and the U.S. (Models based on cross-sectional data)

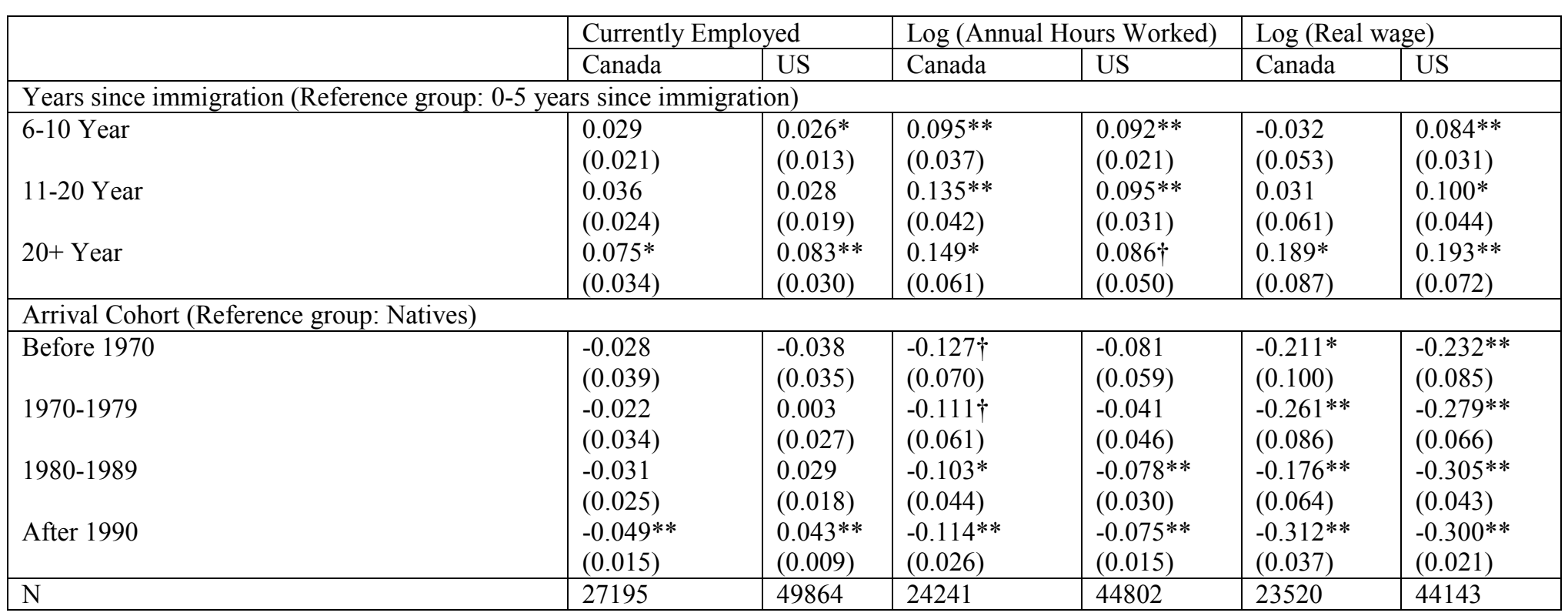

Notes: See notes to Table 1 for sample specification. Each column is a separate regression. Models control for age, education, year of observation, and state/province of residence, year and age interactions, and year and education interactions.

$* * \mathrm{p} \leq .01, *$ for $0.01<\mathrm{p} \leq .05$, and $\dagger$ for $0.05<\mathrm{p} \leq .1$ 
Appendix Table 1: Descriptive Statistics

\begin{tabular}{|c|c|c|c|c|c|c|}
\hline & \multicolumn{2}{|c|}{ Employment rates } & \multicolumn{2}{|c|}{ Annual Hours worked } & \multicolumn{2}{|c|}{ Hourly wage } \\
\hline & Canada & US & Canada & US & $\begin{array}{c}\text { Canada } \\
\text { (CAD \$s) }\end{array}$ & $\begin{array}{c}\mathrm{US} \\
\text { (US \$s) }\end{array}$ \\
\hline Nativity & & & & & & \\
\hline Native-Born & 0.91 & 0.92 & 2111 & 2302 & 19.84 & 16.60 \\
\hline Foreign-Born & 0.91 & 0.94 & 2097 & 2185 & 19.74 & 13.60 \\
\hline Years Since Immigration & & & & & & \\
\hline $0-5$ Year & 0.90 & 0.96 & 1947 & 2136 & 17.59 & 12.34 \\
\hline 6-10 Year & 0.92 & 0.97 & 2085 & 2226 & 16.47 & 12.34 \\
\hline 11-15 Year & 0.92 & 0.95 & 2141 & 2248 & 19.68 & 13.71 \\
\hline$>21$ Year & 0.90 & 0.92 & 2147 & 2234 & 22.87 & 17.02 \\
\hline$\underline{\text { Region of Origin }}$ & & & & & & \\
\hline Europe & 0.92 & 0.94 & 2148 & 2323 & 21.93 & 19.15 \\
\hline Latin America & 0.91 & 0.95 & 1981 & 2123 & 17.05 & 9.73 \\
\hline Africa and the Middle East & 0.85 & 0.96 & 2134 & 2260 & 19.49 & 16.86 \\
\hline Asia & 0.92 & 0.94 & 2063 & 2254 & 18.15 & 18.36 \\
\hline
\end{tabular}

Note: The samples correspond to the male analytic samples in Tables 2-4 during their first observed year. 
Appendix Table 2: Estimates of Labor Market Outcomes of Native-born and Immigrant Men in Canada and the U.S. (Models using longitudinal data with longitudinal weights and individual fixed effects)

\begin{tabular}{|c|c|c|c|c|c|c|}
\hline & \multicolumn{2}{|c|}{ Currently Employed } & \multicolumn{2}{|c|}{ Log Annual Hours Worked } & \multicolumn{2}{|c|}{ Log real Wage } \\
\hline & Canada & U.S. & Canada & U.S. & Canada & U.S. \\
\hline \multicolumn{7}{|l|}{ Model 1} \\
\hline \multirow[t]{2}{*}{ Trend } & $-0.006 * *$ & $-0.009 * *$ & $-0.005 \dagger$ & $-0.016^{* *}$ & $0.022 * *$ & $0.015 * *$ \\
\hline & $(0.001)$ & $(0.001)$ & $(0.002)$ & $(0.001)$ & $(0.002)$ & $(0.002)$ \\
\hline \multirow[t]{2}{*}{ Foreign-born*trend } & -0.003 & $0.005^{*}$ & -0.002 & $0.025 * *$ & -0.002 & 0.007 \\
\hline & $(0.003)$ & $(0.002)$ & $(0.007)$ & $(0.004)$ & $(0.007)$ & $(0.005)$ \\
\hline \multicolumn{7}{|l|}{ Model 2} \\
\hline \multirow[t]{2}{*}{ Trend } & $-0.006 * *$ & $-0.009 * *$ & $-0.005 \dagger$ & $-0.016 * *$ & $0.022 * *$ & $0.015 * *$ \\
\hline & $(0.001)$ & $(0.001)$ & $(0.002)$ & $(0.001)$ & $(0.002)$ & $(0.002)$ \\
\hline \multirow[t]{2}{*}{$\mathrm{YSI}=0-5 \mathrm{yrs} *$ trend } & $0.009 \dagger$ & $0.011 * *$ & 0.013 & $0.048 * *$ & $0.025 \dagger$ & $0.022 *$ \\
\hline & $(0.005)$ & $(0.003)$ & $(0.017)$ & $(0.010)$ & $(0.015)$ & $(0.011)$ \\
\hline \multirow[t]{2}{*}{ YSI $=6-10 \mathrm{yrs} *$ trend } & $0.010^{*}$ & -0.002 & -0.002 & 0.007 & -0.006 & $0.034 * *$ \\
\hline & $(0.005)$ & $(0.006)$ & $(0.016)$ & $(0.007)$ & $(0.019)$ & $(0.011)$ \\
\hline \multirow[t]{2}{*}{ YSI $=11-20 \mathrm{yrs} *$ trend } & 0.001 & $0.005^{*}$ & 0.005 & $0.011 \dagger$ & -0.016 & -0.006 \\
\hline & $(0.006)$ & $(0.002)$ & $(0.009)$ & $(0.006)$ & $(0.012)$ & $(0.010)$ \\
\hline \multirow[t]{2}{*}{ YSI $>20$ yrs*trend } & $-0.022 * *$ & $0.014 * *$ & $-0.021 *$ & $0.021 * *$ & -0.006 & -0.003 \\
\hline & $(0.005)$ & $(0.004)$ & $(0.010)$ & $(0.007)$ & $(0.010)$ & $(0.012)$ \\
\hline \multicolumn{7}{|l|}{ Model 3} \\
\hline \multirow[t]{2}{*}{ Trend } & $-0.006 * *$ & $-0.009 * *$ & $-0.005 \dagger$ & $-0.016 * *$ & $0.022 * *$ & $0.015 * *$ \\
\hline & $(0.001)$ & $(0.001)$ & $(0.002)$ & $(0.001)$ & $(0.002)$ & $(0.002)$ \\
\hline \multirow[t]{2}{*}{ Europe*trend } & $-0.010^{*}$ & 0.006 & 0.008 & $0.024 *$ & -0.004 & 0.008 \\
\hline & $(0.004)$ & $(0.004)$ & $(0.010)$ & $(0.012)$ & $(0.012)$ & $(0.015)$ \\
\hline \multirow[t]{2}{*}{ Latin America*trend } & -0.010 & 0.002 & -0.013 & $0.020 * *$ & -0.021 & $0.012 \dagger$ \\
\hline & $(0.010)$ & $(0.003)$ & $(0.015)$ & $(0.005)$ & $(0.020)$ & $(0.006)$ \\
\hline \multirow[t]{2}{*}{ Africa \& Middle East*trend } & 0.004 & 0.001 & -0.004 & $0.060 * *$ & -0.016 & -0.005 \\
\hline & (0.009) & $(0.006)$ & $(0.016)$ & $(0.021)$ & $(0.024)$ & $(0.027)$ \\
\hline \multirow[t]{2}{*}{ Asia*trend } & 0.003 & $0.010 * *$ & -0.007 & $0.027 * *$ & 0.009 & -0.005 \\
\hline & $(0.004)$ & $(0.003)$ & $(0.011)$ & $(0.007)$ & $(0.010)$ & $(0.011)$ \\
\hline $\mathrm{N}$ & 95531 & 93595 & 82579 & 83045 & 79565 & 81779 \\
\hline
\end{tabular}

Notes: See notes to Table 2. ${ }^{* *} \mathrm{p} \leq .01, *$ for $0.01<\mathrm{p} \leq .05$, and $\dagger$ for $0.05<\mathrm{p} \leq .1$. These models use longitudinal weights. 
Appendix Table 3: Estimates of Labor Market Outcomes of Native-born and Immigrant Men in Canada and the U.S.

(Models using longitudinal data with individual fixed effects: Sample: Individuals present in all years of a panel)

\begin{tabular}{|c|c|c|c|c|c|c|}
\hline & \multicolumn{2}{|c|}{ Currently Employed } & \multicolumn{2}{|c|}{ Log Annual Hours Worked } & \multicolumn{2}{|c|}{ Log real Wage } \\
\hline & Canada & U.S. & Canada & U.S. & Canada & U.S. \\
\hline $\begin{array}{l}\text { Model } 1 \\
\text { Trend } \\
\text { Foreign-born*trend }\end{array}$ & $\begin{array}{l}-0.009 * * \\
(0.001) \\
-0.001 \\
(0.002)\end{array}$ & $\begin{array}{l}-0.010^{* *} \\
(0.000) \\
0.005^{* *} \\
(0.001)\end{array}$ & $\begin{array}{l}-0.007 * * \\
(0.001) \\
0.006 \\
(0.005) \\
\end{array}$ & $\begin{array}{l}-0.014 * * \\
(0.001) \\
0.016^{* *} \\
(0.003)\end{array}$ & $\begin{array}{l}0.024 * * \\
(0.001) \\
-0.000 \\
(0.005) \\
\end{array}$ & $\begin{array}{l}0.016^{* *} \\
(0.001) \\
0.011^{* *} \\
(0.004) \\
\end{array}$ \\
\hline Model 2 & & & & & & \\
\hline Trend & $\begin{array}{l}-0.009 * * \\
(0.001)\end{array}$ & $\begin{array}{l}-0.010^{* *} \\
(0.000)\end{array}$ & $\begin{array}{l}-0.007 * * \\
(0.001)\end{array}$ & $\begin{array}{l}-0.014 * * \\
(0.001)\end{array}$ & $\begin{array}{l}0.024 * * \\
(0.001)\end{array}$ & $\begin{array}{l}0.016^{* *} \\
(0.001)\end{array}$ \\
\hline YSI $=0-5$ yrs*trend & $\begin{array}{l}0.010^{*} \\
(0.005)\end{array}$ & $\begin{array}{l}0.013^{* *} \\
(0.003)\end{array}$ & $\begin{array}{l}0.018 \\
(0.011)\end{array}$ & $\begin{array}{l}0.039 * * \\
(0.007)\end{array}$ & $\begin{array}{l}0.040^{* *} \\
(0.012)\end{array}$ & $\begin{array}{l}0.038^{* *} \\
(0.008)\end{array}$ \\
\hline YSI $=6-10 \mathrm{yrs} *$ trend & $\begin{array}{l}0.014^{* *} \\
(0.005)\end{array}$ & $\begin{array}{l}0.004 \\
(0.003)\end{array}$ & $\begin{array}{l}0.010 \\
(0.011)\end{array}$ & $\begin{array}{l}0.009 \\
(0.006)\end{array}$ & $\begin{array}{l}0.010 \\
(0.011)\end{array}$ & $\begin{array}{l}0.022 * * \\
(0.008)\end{array}$ \\
\hline YSI $=11-20 \mathrm{yrs} *$ trend & $\begin{array}{l}0.001 \\
(0.004)\end{array}$ & $\begin{array}{l}0.004 \dagger \\
(0.002)\end{array}$ & $\begin{array}{l}0.003 \\
(0.009)\end{array}$ & $\begin{array}{l}0.010 \dagger \\
(0.005)\end{array}$ & $\begin{array}{l}-0.001 \\
(0.009)\end{array}$ & $\begin{array}{l}0.002 \\
(0.006)\end{array}$ \\
\hline YSI $>20$ yrs*trend & $\begin{array}{l}-0.012 * * \\
(0.003)\end{array}$ & $\begin{array}{l}0.008^{*} \\
(0.003) \\
\end{array}$ & $\begin{array}{l}0.002 \\
(0.007) \\
\end{array}$ & $\begin{array}{l}0.011 \\
(0.007) \\
\end{array}$ & $\begin{array}{l}-0.023 * * \\
(0.008)\end{array}$ & $\begin{array}{l}0.005 \\
(0.009) \\
\end{array}$ \\
\hline Model 3 & & & & & & \\
\hline Trend & $\begin{array}{l}-0.009^{* *} \\
(0.001)\end{array}$ & $\begin{array}{l}-0.010^{* *} \\
(0.000)\end{array}$ & $\begin{array}{l}-0.007 * * \\
(0.001)\end{array}$ & $\begin{array}{l}-0.014^{* *} \\
(0.001)\end{array}$ & $\begin{array}{l}0.024^{* *} \\
(0.001)\end{array}$ & $\begin{array}{l}0.016^{* *} \\
(0.001)\end{array}$ \\
\hline Europe*trend & $\begin{array}{l}-0.008^{* *} \\
(0.003)\end{array}$ & $\begin{array}{l}0.008^{*} \\
(0.003)\end{array}$ & $\begin{array}{l}0.013 \dagger \\
(0.007)\end{array}$ & $\begin{array}{l}0.018^{*} \\
(0.007)\end{array}$ & $\begin{array}{l}-0.007 \\
(0.007)\end{array}$ & $\begin{array}{l}0.007 \\
(0.009)\end{array}$ \\
\hline Latin America*trend & $\begin{array}{l}-0.003 \\
(0.006)\end{array}$ & $\begin{array}{l}0.003 \dagger \\
(0.002)\end{array}$ & $\begin{array}{l}0.003 \\
(0.015)\end{array}$ & $\begin{array}{l}0.018^{* *} \\
(0.004)\end{array}$ & $\begin{array}{l}0.009 \\
(0.015)\end{array}$ & $\begin{array}{l}0.013^{* *} \\
(0.005)\end{array}$ \\
\hline Africa \& Middle East*trend & $\begin{array}{l}0.013^{*} \\
(0.006)\end{array}$ & $\begin{array}{l}-0.002 \\
(0.005)\end{array}$ & $\begin{array}{l}-0.003 \\
(0.016)\end{array}$ & $\begin{array}{l}0.037 * * \\
(0.012)\end{array}$ & $\begin{array}{l}-0.013 \\
(0.016)\end{array}$ & $\begin{array}{l}0.012 \\
(0.015)\end{array}$ \\
\hline Asia*trend & $\begin{array}{l}0.005 \\
(0.003) \\
\end{array}$ & $\begin{array}{l}0.009^{* *} \\
(0.003)\end{array}$ & $\begin{array}{l}0.002 \\
(0.008) \\
\end{array}$ & $\begin{array}{l}0.006 \\
(0.006) \\
\end{array}$ & $\begin{array}{l}0.008 \\
(0.008)\end{array}$ & $\begin{array}{l}0.008 \\
(0.007)\end{array}$ \\
\hline $\mathrm{N}$ & 70568 & 112092 & 56284 & 93118 & 53340 & 90296 \\
\hline
\end{tabular}

Notes: See notes to Table $2 .{ }^{* *} \mathrm{p} \leq .01,{ }^{*}$ for $0.01<\mathrm{p} \leq .05$, and $\dagger$ for $0.05<\mathrm{p} \leq .1$. Samples are restricted to individuals present in all years of a panel. 